\title{
Las limitadas potestades del registro de asociaciones de Euskadi en la solicitud de inscripción de actos: el mandato real del capítulo XI de la Ley de Asociaciones de Euskadi
}

The limited authority of the associations register of Euskadi in applying to register documents: real mandate of chapter XI of the associations law of Euskadi

Jokin Babaze Aizpurua

Abogado

Secretario de la Asociación Donostiarra de Amigos de la Ópera

Resumen: La actual Ley de Asociaciones establece la obligación de proceder a la inscripción registral de algunos actos, cuya inscripción registral es a su vez necesaria para la efectiva operatividad de la asociación. Aunque tanto la Constitución como las Leyes de Asociaciones establezcan que el Registro se realiza a los meros efectos de la publicidad y que la solicitud tan solo podrá ser rechazada cuando existan defectos de forma, el Registro de Asociaciones del País Vasco acostumbra a utilizar dicha norma para requerir modificaciones de fondo de los acuerdos cuya inscripción se solicita. Entendemos que dichos requerimientos son contrarios a la configuración constitucional y legal del derecho de asociación, y que si el objetivo del Registro de Asociaciones es tratar de evitar que se publiciten actos que pudieran ser contrarios a derecho el mecanismo para hacer efectivo este objetivo debería ser otro, que no evite la efectiva inscripción solicitada.

Palabras clave: Registro de Asociaciones; inscripción de junta directiva; Inscripción de estatutos; derecho de autoorganización; autonomía privada.

\begin{abstract}
The current Associations Law sets forth the obligation to register certain documents at the register, whose registration, in turn, is required to effectively operate the association. Although both the Constitution and the Associations Law set forth that the Register is merely for publicity purposes and that the application may only be denied when there are formal defects, the Associations Register of the Basque Country typically uses this regulation to require substantive amendments to the agreements being applied for registration. We understand that these requirements contradict the constitutional and legal framework for association law, and that if the objective of the Associations Register is to attempt to prevent documents from being publicised that may contradict the law, the mechanism to reach this objective should be another, one that does not prevent effective registration after application.
\end{abstract}

Keywords: Associations Register; registration of board of directors; registration of bylaws; right to selforganisation; private autonomy.

Claves Econlit: K23, D73, D71. L31

* Correspondencia a/Corresponding author: Jokin Babaze Aizpurua. Asociación Donostiarra de Amigos de la Ópera jbabaze@gmail.com

Cómo citar/How to cite: Babaze Aizpurua, Jokin (2019). "Las limitadas potestades del registro de asociaciones de Euskadi en la solicitud de inscripción de actos: el mandato real del capítulo XI de la Ley de Asociaciones de Euskadi», Gizarte Ekonomiaren Euskal Aldizkaria/Revista Vasca de Economía Social, 16, 29-47. (https://doi.org/10.1387/reves.20719).

Recibido: 27 marzo, 2019; aceptado: 30 septiembre, 2019.

ISSN 1698-7446 - elSSN 2444-3107 / (c) 2019 UPV/EHU

cc) Esta obra está bajo una licencia

Creative Commons Atribución 4.0 Internacional 


\section{Introducción: sobre la razón de ser de este trabajo}

El régimen jurídico de las asociaciones es sobradamente conocida, y en apariencia pacífica, en el ámbito académico y judicial en tanto manifestación del derecho de asociación consagrado en la Constitución.

Sobre los supuestos en los que podría convenir la investigación jurídica en relación a la aplicación del derecho de asociaciones, Bermejo Vera $(1995,120)$ decía que «naturalmente, los Tribunales no están para imaginar problemas, sino para resolverlos, o para diseñar soluciones novedosas, sino para dar respuestas jurídicamente fundadas. Al parecer, no son muchos los problemas que se plantean, o no son suficientemente arduos como para haber merecido mayor atención doctrinal y jurisprudencial». Aunque ciertamente ha habido pronunciamientos judiciales y se han publicado trabajos muy interesantes que, directa o indirectamente, realizan notorias aportaciones al derecho de asociación, la realidad 24 años después sigue siendo relativamente similar en algunos aspectos del derecho de asociación cómo puede ser el procedimiento de inscripción en el registro correspondiente: no parece que en esta manifestación del ejercicio del derecho de asociación se planteen los problemas suficientes como para ocuparse de este asunto en detalle.

En nuestra opinión, las causas reales de esa falta de doctrina académica y jurisprudencial en algunas cuestiones de detalle del régimen jurídico de las Asociaciones son otras, bastante más prosaicas: los duelos jurídicos en materia de derecho de asociaciones pueden ser jurídicamente sustanciales, pero no son económicamente sustanciosas. La naturaleza no lucrativa de las asociaciones, si bien ocasiona que la peleas intestinas sean especialmente encarnizadas y humanamente desagradables por tratarse de luchas con un fondo eminentemente sentimental, trae sin embargo como consecuencia ineludible que salvo contadas excepciones dichas peleas no afecten al patrimonio de los asociados, y que por tanto en la gran mayoría de ocasiones estos no tengan la motivación suficiente para iniciar un proceso judicial cuando el marco en el que se resolverá el conflicto no es claro, precisamente por dicha ausencia de doctrina académica y jurisprudencial. Es, dicho llanamente, la pescadilla que se muerde la cola, y hay muy pocas ocasiones en las que alguien se ve lo suficientemente motivado como para intentar cambiar la inercia en su caso concreto.

La defensa del asociacionismo pasa por tanto en este caso por remarcar el auténtico carácter de las normas que las regulan, en el sentido de que los intereses de las personas que pretenden ejercer su derecho de asociación se vean lo menos perjudicadas posibles.

En relación con lo anterior, las cuestiones relativas a la inscripción registral de las asociaciones, de capital importancia para su vida jurídica 
como luego se tratará de demostrar, tienen un especial interés jurídicopractico en el derecho de asociaciones, ya que resulta una pieza fundamental para el normal desarrollo de la actividad de las mismas.

En este sentido, la tramitación de dicha inscripción registral ha sido habitualmente gestionada por el Registro de Asociaciones del País Vasco desde la premisa de que el Capítulo XI de la Ley Vasca de Asociaciones supone que la administración debe controlar el contenido del acto jurídico cuya inscripción se solicita, siendo frecuente en la práctica observar casos en los que el Registro de Asociaciones remite requerimientos de subsanación de textos estatutarios por considerar que son de un contenido contrario a la Ley de Asociaciones del País Vasco o a la Ley Orgánica de Asociaciones, requerimientos de subsanación por considerar que determinado apartado del texto estatutario debería estar redactado de otra forma al tiempo que propone el contenido exacto del texto que aseguraría a su inscripción en el registro etc.

La práctica totalidad de las Asociaciones, bien sea porque carezcan de recursos (sean económicos, técnicos o intelectuales) para oponerse ellos, bien sea porque teman "enfrentarse al Leviatán», se pliegan a dichos requerimientos de subsanación, lo cual en su caso más extremo puede llegar a suponer modificar el texto estatutario sin previa aprobación de la Asamblea General.

Sin embargo en nuestra opinión, todos estos requerimientos exceden tanto de las funciones constitucionales del registro de asociaciones cómo de la regulación qué la ley vasca de asociaciones establece respecto a la $\mathrm{Li}$ bertad de las asociaciones para definir su propia regulación cómo a la tramitación de las inscripciones obligatorias establecidas por ley.

Por ello, desde el de vista de la protección de la efectiva realización del derecho de asociación como forma de fomentar dicho tipo de organización social, consideramos conveniente remarcar los importantes motivos jurídicos que subyacen en el fondo del contenido del capítulo XI de la ley de asociaciones, y en concreto la lógica jurídica por la cual el Registro de Asociaciones no tiene legitimidad para impedir la inscripción de los actos jurídicos que se presenten en el Registro, y menos aun para solicitar que se modifiquen en un sentido determinado.

\section{La obligación de las asociaciones de publicitar sus actos mediante inscripción en el Registro y la necesidad de las mismas de conseguir dicha inscripción}

Como es sabido, la Constitución Española reconoce el Derecho de Asociación en su art. 22, dentro de la Sección Primera del Capitulo Se- 
gundo del Titulo Primero, es decir, dentro de los derechos y libertades fundamentales. Esta incardinación constitucional tiene consecuencias jurídicas muy relevantes: 1) La necesidad de interpretar dicho artículo de conformidad con la declaración de los derechos humanos y los tratados y acuerdos internacionales sobre la materia ratificados por España y 2) la necesidad de regular el ejercicio de ese derecho por Ley Orgánica.

En relación a los tratados y acuerdos internacionales sobre derechos humanos ratificados por España deben destacarse el art. 20 de la Declaración Universal de Derechos Humanos y el art. 22 de la Pacto Internacional de Derechos Civiles y Políticos, que dice que 1. Toda persona tiene derecho a asociarse libremente con otras, incluso el derecho a fundar sindicatos y afiliarse a ellos para la protección de sus intereses, y 2. El ejercicio de tal derecho sólo podrá estar sujeto a las restricciones previstas por la ley que sean necesarias en una sociedad democrática, en interés de la seguridad nacional, de la seguridad pública o del orden público, o para proteger la salud o la moral públicas o los derechos y libertades de los demás. El presente artículo no impedirá la imposición de restricciones legales al ejercicio de tal derecho cuando se trate de miembros de las fuerzas armadas y de la policía.

Por otro lado, el desarrollo legislativo del derecho de asociación se ha realizado, sin perjuicio de desarrollo legislativo por las Comunidades Autónomas con competencias en la materia, por LO 1/2002, algunos de cuyos preceptos tienen aplicación directa en todo el Estado, conforme a la Disposición Final Primera de dicha Ley Orgánica.

Finalmente, hay que recordar que la Constitución ha distinguido la legitimidad constitucional los tipos de persona jurídica que enumera el decimonónico Código Civil en su art. 35, cuya personalidad comienza, en el caso de las personas jurídicas de interés público, desde el instante mismo en que, con arreglo a derecho, hubiesen quedado válidamente constituidas, y en el caso de las personas jurídicas de interés particular, cuando la ley conceda personalidad propia. Así, no es baladí la diferencia en la regulación constitucional de las Asociaciones respecto a las otras personas jurídicas privadas, que se entroncan en el art. 34 en el caso de las fundaciones y en el art. 38 en el de las sociedades mercantiles, cuyas potestades de creación se configuran como derechos de los ciudadanos, pero no como derechos fundamentales.

Así, debidamente contextualizado, el art. $22 \mathrm{CE}$ resulta del siguiente tenor literal:

1. Se reconoce el derecho de asociación.

2. Las asociaciones que persigan fines o utilicen medios tipificados como delito son ilegales.

3. Las asociaciones constituidas al amparo de este artículo deberán inscribirse en un registro a los solos efectos de publicidad. 
4. Las asociaciones sólo podrán ser disueltas o suspendidas en sus actividades en virtud de resolución judicial motivada.

5. Se prohiben las asociaciones secretas y las de carácter paramilitar.

Por lo tanto, si bien ya el texto constitucional impone la obligación de la inscripción registral, prohibiendo las asociaciones secretas, Establece también que dicha inscripción tendrá como único efecto su publicidad, procurando así a los ciudadanos dar la mayor libertad posible al ejercicio de este derecho.

Tal y como dice Isabel Marín Gómez, es importante subrayar la referencia constitucional al registro y la disolución, «ya que evidencian la relevancia que adquirió el movimiento asociativo en ese momento - como se verá más adelante- ante las especiales características que presentaba el Registro de Asociaciones franquista, sometiendo a una extremada burocracia, basada en el control y la represión, la constitución, el desarrollo y el funcionamiento de las asociaciones que se creaban al amparo de la Ley de 1964, supuestamente "aperturista», ocasionando verdaderas trabas en todos los ámbitos de la actividad asociativa, y que dieron lugar a diversas acciones reivindicativas y posturas de oposición, encauzadas desde y a través de las propias asociaciones; evidenciando así los cambios sociales que se habían producido y del potencial social que daría lugar al cambio político en la transición a la democracia, así como su importante aportación al consenso democrático» (Marín Gómez, 2016).

Dicha previsión constitucional debe ponerse en relación con la regulación franquista de la Ley de Asociaciones de 1964, en la que el Registro de Asociaciones fue otro instrumento de control de la sociedad por la Administración. Siguiendo a Isabel Marín Gómez «La exhaustiva acción protocolaria y burocrática de la inscripción en el registro, conforme establecía la ley, y la magnitud de las anotaciones que debían practicarse en cada momento, da idea de cómo se veía afectada la vida de la asociación por el control estatal. La necesidad de autorización administrativa condicionaba especialmente las principales acciones de la asociación, como eran su inscripción inicial y sus modificaciones estatutarias, lo que implicaba que la asociación no podía realizar las actividades previstas en sus estatutos, o ejercer una acción propuesta o solicitada, en tanto no se encontrase registrada o inscrita, mediante la anotación debidamente autorizada, único momento en el que nacía el derecho.

De esta forma, el registro quedaba configurado como un mecanismo de demora de los efectos de la constitución de la asociación, o de las alteraciones que en la misma se acordaran por los asociados, y más aún cuando, en ese mismo sentido, se establecía el régimen de reuniones que celebrasen las asociaciones, ya que no se podía utilizar el local social en tanto no se 
encontrara debidamente inscrita la asociación, como tampoco podían celebrarse las preceptivas asambleas generales o extraordinarias sin la previa autorización gubernativa.

El hecho de que toda actuación o actividad de la asociación hubiera de pasar siempre por su anotación de oficio en el registro, suponía para la Administración, como reiteraba Blanca Olías, una vía libre a las posibilidades de recurrir a los «instrumentos de retorsión", o mecanismos de coerción. Aunque la ley establecía taxativamente unos plazos para llevar a cabo las inscripciones exigidas, no ofrecía ninguna garantía a los particulares para cubrir la eventualidad de una demora en las mismas. Si la asociación se encontraba ante esa demora, quedaba involuntariamente al margen de la ley y, consecuentemente, ante el riesgo de sanción, e incluso de suspensión» (Marín Gómez, 2016).

Ese control es precisamente lo que en desarrollo de la Constitución la LODA y la LVA quieren evitar, al expresar sendos textos legislativos que el desarrollo de la legislación debe realizarse con «respeto a la libertad asociativa y con la no injerencia en su funcionamiento interno, para que bajo el pretexto del fomento no se cobijen formas de intervencionismo contrarias a nuestra norma suprema» (Exposición de Motivos LODA) y que "la presente ley descansa sobre la concepción del derecho de asociación como un derecho fundamental y una libertad pública consagrados por el texto constitucional, asi como sobre el principio de libertad civil, tan caro al Derecho foral vasco, y los conceptos indisolubles de libertad y responsabilidad» (Exposición de Motivos Ley Vasca de Asociaciones).

Es por ello que observamos diferencias sustanciales en sendas normas especiales en relación la importancia de la inscripción registral en la adquisición de la personalidad de los distintos tipos de personas jurídicas, Ya que tanto las fundaciones como las sociedades de capital adquieren su personalidad jurídica desde la inscripción de la escritura pública correspondiente en su respectivo registro (art. 4 Ley 50/2002 De fundaciones y art. 33 Ley 10/2010, de Sociedades de Capital), La Ley Orgánica de asociaciones establece expresamente que "con el otorgamiento del acta adquirirá la asociación su personalidad jurídica y la plena capacidad de obrar, sin perjuicio de la necesidad de su inscripción a los efectos del artículo 10» (art. 5.2 LO 1/2002), por lo que las Asociaciones adquieren su capacidad jurídica y de obrar desde el momento en que tres o más personas acuerdan constituir una Asociación y aprobar sus Estatutos, independientemente de su inscripción, que se realiza, conforme al art. 22.3 CE, a los solos efectos de publicidad.

Ahora bien, aunque la Ley señale que la Asociación adquiere plena capacidad de obrar desde el momento en que concurra dicha voluntad de los fundadores, esa afirmación debe ser matizada, al menos desde un punto de vista jurídico-práctico: en una sociedad acostumbrada hace años a rea- 
lizar todas las transacciones económicas por medio de cuentas bancarias, e inmersa ya (al menos desde la aprobación de la Ley 39/2015, de Procedimiento Administrativo Común) en la Administración Electrónica, la capacidad de obrar plena solo podrá ostentarse de facto desde el momento en que la Asociación cuente con las herramientas necesarias para su efectivo ejercicio. Esto supone que, en todo caso, la Asociación deberá proceder al alta en el Impuesto de Actividades Económicas para obtener el Número de Identificación Fiscal que le permita tanto abrir una cuenta corriente como conseguir la efectiva identificación a los efectos de los trámites a realizar para con la Administración, lo cual requerirá que esté debidamente inscrita en el Registro correspondiente.

Por lo tanto, la inscripción registral será condición sine qua non para la efectiva adquisición de la capacidad de obrar de la Asociación, y no resultará neutro el hecho de que se consiga, a la mayor brevedad posible y conforme a lo que la propia asociación ha decidido, la efectiva inscripción de la asociación, de sus estatutos o de su Junta directiva en el registro de asociaciones.

\section{La tramitación de la solicitud de inscripción en el Registro de Asociaciones del País Vasco}

De acuerdo al artículo 37 de la Ley Vasca de Asociaciones, el derecho de asociación incluye el derecho a la inscripción en el registro de asociaciones competente, que sólo podrá denegarse cuando no se reúnan los requisitos establecidos en la legislación vigente. Es interesante señalar en este punto que el art. 10 de la LO de Asociaciones, que tiene carácter de Ley Orgánica, tiene un texto casi idéntico, con la diferencia de que, en lugar de decir que la inscripción sólo podrá denegarse «cuando no se reúnan los requisitos establecidos en la legislación vigente», dice que sólo podrá denegarse cuando no se reúnan los requisitos establecidos «en la presente Ley Orgánica», de modo que, en principio, no cabe añadir requisitos adicionales a la de dicha LO para la denegación de las solicitudes de inscripción.

Es el art. 39 de la LVA el que establece los actos que deben ser objeto de inscripción, estableciendo que deberán inscribirse en el Registro General de Asociaciones del País Vasco, además del reconocimiento de utilidad pública y su revocación, la constitución de la asociación; la modificación de estatutos; la designación de los miembros de la Junta Directiva así como sus variaciones; la incorporación o baja en federaciones y confederaciones y los acuerdos de disolución, fusión y transformación y, en su caso, el traslado a otro registro; siendo todas ellas decisiones cuya adopción compete en exclusiva a la Asamblea General de acuerdo al art. 16.3 LVA. 
Por su parte, el art. 40 LVA, que se titula «Régimen jurídico de las inscripciones», establece lo siguiente sobre la tramitación de las solicitudes de inscripción:

1. La solicitud de inscripción de la constitución de una asociación irá acompañada del acta de constitución firmada por todas las personas promotoras, de los estatutos firmados por el presidente o la presidenta y el secretario o la secretaria y de la relación nominativa de las personas que integran los órganos de representación y gobierno.

2. Las inscripciones se practicarán en el plazo máximo de tres meses desde la presentación de toda la documentación necesaria en el Registro General de Asociaciones del País Vasco. Transcurrido este plazo sin que se haya notificado resolución expresa, se entenderá estimada la solicitud.

3. Cuando se adviertan defectos formales en la solicitud o en la documentación que la acompaña, o cuando la denominación coincida con otra inscrita o pueda inducir a error o confusión con ella, o cuando la denominación coincida con una marca registrada o notoria, salvo que se solicite por su titular o con su consentimiento, se suspenderá el plazo para proceder a la inscripción y se abrirá otro de 10 días para la subsanación de los defectos advertidos.

4. Cuando la entidad solicitante no se encuentre incluida en el ámbito de aplicación de la presente ley o no tenga naturaleza de asociación, el registro general, previa audiencia de la entidad, denegará su inscripción e indicará al solicitante cuál es el registro u órgano administrativo competente para inscribirla. La denegación será siempre motivada.

5. Si se encontraren indicios racionales de ilicitud penal en la constitución de la asociación, el órgano competente dictará una resolución motivada y dará traslado de toda la documentación al Ministerio Fiscal o al órgano jurisdiccional competente; comunicará esta circunstancia a la entidad interesada y suspenderá el procedimiento administrativo hasta tanto recaiga resolución judicial firme. Se actuará de igual modo si se apreciaren indicios racionales de ilicitud penal en las actividades de una asociación.

Como puede verse, la Ley Vasca de Asociaciones establece una regulación para la tramitación de las solicitudes de inscripción con un plazo de resolución muy breve y con silencio administrativo positivo en el que solo se denegará la inscripción en el caso de que la entidad solicitante no sea una Asociación o no sea del ámbito territorial de la CAPV, y se suspenderá 
en el caso de que se observen indicios de ilicitud penal. También se suspenderá la tramitación cuando se adviertan defectos formales en la solicitud o en la documentación que la acompaña, abriendo un plazo de 10 días para la subsanación de los defectos advertidos.

En la práctica administrativa, dicho art. 40.3 es tradicionalmente empleado por el Registro de Asociaciones para comunicar a las asociaciones la existencia de defectos en los actos cuya inscripción se solicita, tales como una inadecuada redacción de los Estatutos o de la composición de los miembros de la Junta Directiva, requiriéndoles para que en 10 días se subsane la solicitud.

En este punto, podría ser interesante preguntarse si resulta admisible la negativa de la Administración a recibir la documentación en el Registro, cuando falte alguno de los elementos que deben cumplir para su validez. Así, estamos de acuerdo con María Dolores Rego Blanco cuando dice que «ni siguiera cuando tratándose de solicitudes, falte alguno de los elementos que sean de obligado cumplimiento es doctrinalmente admisible que la consecuencia sea que se rechace la recepción por el registro, salvedad hecha naturalmente, de la omisión de los datos que permitan ofrecer subsanación al interesado (que prácticamente se reducen a la identificación de quien subscribe). Cualquier otra deficiencia formal, o la omisión de cualquier otro dato o documento requerido por el ordenamiento jurídico con independencia de que haya o no formulario normalizado para la presentación, habrá de ser valorada por el órgano sustantivamente competente, de manera que, si es subsanable dicho órgano habilitará un trámite para ello; y si no lo es, procederá a adoptar la decisión que corresponda en consecuencia. Los responsables del registro podrán informar a quien presente el escrito acerca de las carencias del mismo y de las posibles consecuencias, pero nunca, entiendo, podrán válidamente rechazar la admisión por incomplitud» (Rego Blanco, 1037).

Así, el Decreto 72/2008, de 29 de abril, de creación, organización, y funcionamiento de los registros de la Administración General de la Comunidad Autónoma de Euskadi y sus Organismos Autónomos establece en su art. 7.f) que no se registrarán en ningún caso aquellos documentos o escritos que carezcan absolutamente de los requisitos mínimos legalmente exigibles.

También resulta interesante reflexionar sobre la naturaleza del procedimiento administrativo de la inscripción registral, sobre la que nos decantamos en configurarla como un procedimiento relativo al ejercicio de un derecho sometido a comunicación previa con silencio administrativo positivo. Esto tiene consecuencias jurídicas ya que, tal y como señala Zambonino Pulito, puede generar el deber de la Administración de no resolver materialmente el procedimiento. 
Así, entendemos que la vía del art. 40.3 LVA es inadecuada para tramitar este tipo de supuestos, por tres razones: 1) el propio texto del art. 40.3 LVA, 2) la naturaleza de los actos a inscribir. y 3) el plazo establecido.

El texto del art. 40.3 LVA: el defecto «formal»

Conforme al art. 3.1 del CC, el caracter «formal» que debe tener el defecto objeto de subsanación debe interpretarse conforme a la definición de la RAE, según la cual «Formal» es " 1 . adj. Perteneciente o relativo a la forma, por contraposición a esenciall. Es decir, que si nos ceñimos a la literalidad del art. 40.3 LVA, las taras de la solicitud que cuya subsanación se reclamen no deben ser relativas a cuestiones de fondo, que son las relativas al contenido del acuerdo que se pretende inscribir.

\section{La naturaleza de los actos a inscribir}

Los actos a inscribir son, como se ha dicho antes, actos cuya decisión debe adoptarse en el seno de la Asamblea General. De estos, nos centraremos un momento en los Estatutos de la entidad, por ser un caso paradigmático de la importancia del acto Como la máxima expresión del derecho de autoorganización que tienen las asociaciones.

Como dice Gómez Montoro, lo que distingue a una Asociación de una mera reunión es la vocación de estabilidad en la actuación conjunta para la consecución de unos fines, actuación conjunta que requiere la formación de una voluntad única. Esa formación de una voluntad única exige, a su vez, que se organice el modo en el que se manifestará válidamente (Gómez Montoro, 99-100). Es decir, que en el momento en que más de una persona deben actuar conjuntamente, es indispensable establecer unas normas: ubi societas, ibi ius. Ocurre que como dice Lucas Murillo de la Cueva $(1996,147)$ «La asociación es, por principio, una unión libre y voluntaria» y que esa libertad supone entre otras cosas la libre determinación de su organización y el desarrollo de la actividad asociativa sin interferencias de ningún tipo por parte de los podes públicos, o lo que es lo mismo, el derecho de autoorganización, que como dice el mismo autor, es un elemento de libertad que tiene una dimensión colectiva, puesto que su titular es la propia asociación y no los socios de la misma «y se ejercita, principalmente, a través de la aprobación de los estatutos» Lucas Murillo de la Cueva (1996, 154-155).

Teniendo en cuenta que los Estatutos son la norma máxima de la Asociación, equiparable a una Constitución en ámbito del Estado, es impor- 
tante que los mismos se amolden a la realidad concreta de la organización y dé respuesta jurídica a sus relaciones internas: del mismo modo en que Ferdinand Lasalle decía que la Constitución es la suma de los factores reales de poder que rigen en ese pais, de manera que si el texto legal que la regula no responde a la Constitución real y efectiva, se arriesga a ser un mero trozo de papel sin aplicación virtual alguna, el texto estatutario debe responder al colectivo cuyas relaciones va a regular, que son los miembros de la Asociación.

Ciertamente, los asociados podrían aplicar normas distintas a las contenidas en los Estatutos, si mejor conveniere a sus intereses individuales y colectivos, pero esta sería una situación de una total fragilidad jurídica, puesto que, tal como dice Iribarren en relación a los pactos parasociales «la variación de uno solo de los socios hace que los pactos parasociales universales pierdan tal condición y con ello, siguiendo la tesis de nuestra mejor doctrina, dejen de poder hacerse valer en la esfera societaria" (Iribarren, M. 2018. 106).

Por ello, el texto estatutario deberá ser cuidadoso en el detalle tanto del colectivo como de la norma. La Asociación podría aprobar unos Estatutos estándar, pero eso, a la postre, no le servirá de nada.

Pero debe tenerse en cuenta que los Estatutos «además de ser un contrato $\mathrm{y}$, además, un mecanismo para contratar $\mathrm{y}$, como tal forzosamente reclama un generoso reconocimiento del principio de autonomía privada que se traduce en el carácter esencialmente dispositivo de su regulación y, por tanto, en la fijación de un marco normativo de mínimos dentro del cual los socios gozan de una amplia autonomía para adaptar la estructura del tipo a sus necesidades a través de los estatutos» (Pérez Escalona, 65), en el sentido de que los Estatutos no solo recogen la voluntad consensuada de los miembros de la Asociación, sino también establecen las fórmulas que en lo sucesivo se aplicarán para formar la voluntad social; son también un documento inscribible en el Registro de Asociaciones y que es habitual que los Estatutos, sobre todo cuando sean producto de una reforma estatutaria, contengan una Disposición Final que establezca que dichos Estatutos entrarán en vigor cuando se inscriban en el Registro correspondiente, convirtiéndose así la inscripción en una auténtica condición suspensiva de la vigencia del contrato.

Así, la solicitud de inscripción de los estatutos o de su modificación conllevará un control por parte de la administración en el cumplimiento de las normas que establece la legislación relativa al Derecho de Asociación, y especialmente lo previsto en el art. 2.5 de la LODA, que establece que «la organización interna y el funcionamiento de las asociaciones deben ser democráticos, con pleno respeto al pluralismo. Serán nulos de pleno derecho los 
pactos, disposiciones estatutarias y acuerdos que desconozcan cualquiera de los aspectos del derecho fundamental de asociación».

Se ha discutido mucho sobre la constitucionalidad de este requisito de democracia interna, no establecido en la Constitución, pero compartimos la idea que transmite González Pérez cuando afirma que «resulta aventurado dar una respuesta en términos categóricos, máxime cuando la referida exigencia, en la medida que no es detallada por la Ley, permite un amplio margen de decisión a la potestad autoorganizativa. En este sentido, aun afectada esa potestad, quizá pudiera concluirse reconociendo la legitimidad de la previsión legal siempre que no se interprete ni aplique en términos indebidamente restrictivos y excluyentes de las muy diversas y variadas posibilidades organizativas y de funcionamiento, todas ellas compatibles, en principio, con la regla de la democracia. [...] Una organización y funcionamiento democráticos seguramente requieren que los acuerdos más trascendentales en la vida de la asociación sean adoptados por todos los asociados reunidos en Asamblea General [...], también en la libre elección de los órganos de gobierno, unipersonales y colegiados, por el conjunto de todos los asociados. Pero la aceptación de cualquier otra concreción resulta ciertamente problemática. [...] Juega aqui, en fin, un limite que, por lo demás, alcanza también a los órganos jurisdiccionales, los cuales, en el ejercicio de su función jurisdiccional, deberán conciliar la exigencia democrática — que, como he dicho, permite diferentes opciones - con la propia potestad autoorganizativa de las asociaciones» (González Pérez, 131-132).

En suma, los actos inscribibles en el Registro de Asociaciones suponen aquellos por los que la Asociación hace efectiva en toda su extensión su facultad de autoorganización, dentro de los límites establecidos por la Ley. En este sentido, la subsanación de los defectos que se señalen por el Registro en el sentido en que se señalen por este, cuando no sean meramente formales, es decir, limitados a la forma de presentar la solicitud (copias, identificación de las personas que presentan la solicitud etc.) supondrá en última instancia sustituir la voluntad de la Asamblea General, ya que se le obligará a modificar su decisión en el sentido en que marque el Registro, toda vez que será a todas luces inaceptable que se proceda a la subsanación de errores en la decisión de la Asamblea General modificando su contenido sin una nueva aprobación por el máximo órgano de la entidad.

En relación a lo anterior, resulta claro que el hecho de forzar a la asociación a adoptar una fórmula determinada en los estatutos es contrario a los derechos de autoorganización y, en el caso concreto del País Vasco, a esa libertad civil tan propia del derecho foral vasco al que hace alusión en la exposición de motivos de la ley vasca de asociaciones. 


\section{Plazo concedido}

Relativo al plazo para la subsanación, hay que observar que dicho plazo de 10 días es el mismo que el que la Ley 39/2015 de Procedimiento Administrativo Común otorga para la subsanación y mejora de la solicitud de inicio del procedimiento en el art. 68, para la realización de los trámites que deban ser cumplimentados por los interesados y para la subsanación de actos de los interesados por falta de requisitos necesarios.

En este caso, teniendo en cuenta que lo que se debe aportar es una decisión corregida de la Asamblea General, y que esta deberá convocarse con al menos 15 días de antelación, resulta claro que es materialmente imposible que se adopte dicho acuerdo en el plazo de 10 días que marca la Ley de Asociaciones.

En resumen, pretender que en un plazo de 10 días, el representante legal de la Asociación aporte documentación relativa a acuerdos de la Asamblea General diferente a la aportada en la primera solicitud es una pretensión que, si se nos permite la reductio ab absurdum por su gran fuerza argumentativa, roza la legalización de la autoría mediata de la falsedad en documento público del art. $390 \mathrm{CP}$.

Por lo tanto, una interpretación sistemática del art. 40.3 LVA conduce lógicamente a concluir que el Registro de Asociaciones no puede requerir por vía de este artículo a las Asociaciones a que modifiquen los actos cuya inscripción soliciten.

\section{La imposibilidad de proceder a la denegación de la inscripción por cuestiones de fondo}

Establecido por tanto que la subsanación de defectos formales no es la vía adecuada para corregir los errores que pudieran existir en el acuerdo adoptado por la Asociación, cabría preguntarse si el Registro de Asociaciones puede, en esos casos, denegar la inscripción del acto que se solicita.

En este punto, debe traerse a colación la Sentencia de la Sala lo Contencioso-Administrativo del Tribunal Supremo de 8 junio 2004, emitida tras la entrada en vigor de la Ley Orgánica 1/2002 pero cuyo proceso comenzó antes de su aprobación, en la que el Alto Tribunal resolvió en casación sobre un litigio ocasionado en torno a la inscripción de una modificación de estatutos que, según los recurrentes, se había acordado con varios defectos relativos al tipo de Asamblea en la que debía producirse y las mayorías exigibles en ella.

En dicha Sentencia, el Tribunal Supremo comienza destacando la radical transformación que en la concepción del derecho de asociación supuso la entrada en vigor de la Constitución de 1978. 
El Supremo recuerda como, en virtud de la Constitución, y en concreto de lo dispuesto en sus artículos 1.1, 9.2, 10.1 y 22, nuestro ordenamiento jurídico pasó desde la desconfianza preconstitucional que sujetaba a las asociaciones a un control preventivo por parte de la Administración, a una concepción plenamente respetuosa de la libertad del ciudadano, al que se le reconoce también, y con el carácter de derecho fundamental, la posibilidad de agruparse y organizarse para la consecución de cualesquiera fines lícitos, al margen del Estado y, por tanto, sin interferencia estatal alguna, sólo admisible de modo preventivo en presencia de genuinas razones de orden público. Se comprende, pues, que en buena parte de la doctrina científica y en la doctrina del Tribunal Constitucional latiera la idea de que la Ley 191/1964, sustentada en un sistema de control preventivo, había quedado derogada, no en su totalidad, pero sí en numerosos de sus preceptos, como consecuencia directa de lo ordenado en el número 3 de la Disposición Derogatoria contenida en el Texto Constitucional.

De un lado, lo dispuesto en el número 4 de aquel artículo 22, conforme al cual, las asociaciones sólo podrán ser disueltas o suspendidas en sus actividades en virtud de resolución judicial motivada, pues esta reserva de jurisdicción debe conllevar, precisamente para impedir cualquier interferencia de otros poderes que ponga en peligro el libre desenvolvimiento de las actividades asociativas, que sólo el Poder Judicial y no la Administración pueda resolver sobre la validez o nulidad de las cláusulas de sus Estatutos. Y, de otro, lo dispuesto en el número 3 de aquel mismo artículo, conforme al cual, las asociaciones constituidas al amparo de este artículo deberán inscribirse en un registro a los solos efectos de publicidad, pues siendo esto así, ello ha de significar que la autoridad administrativa encargada del registro no pueda efectuar más que un control de la apariencia externa de legalidad del documento o documentos que contienen los datos que han de ser publicados, verificando, tan sólo, si quien los presenta ostenta poderes de representación de la asociación que le faculten para ello y si reflejan o dan cuenta de un acuerdo de ésta sobre datos que deban ser objeto de publicidad registral. Como dijo el Tribunal Constitucional en su sentencia número 85/1986, de 25 de junio, referida a un partido político, pero sentando una doctrina perfectamente aplicable para precisar el significado del deber de inscripción a los solos efectos de publicidad que impone el número 3 del artículo 22, el sistema de previa inscripción en un Registro público sólo es constitucionalmente admisible con el alcance de un control formal externo y de naturaleza estrictamente reglada por parte de la autoridad administrativa, cuyo encargado no tiene más funciones que las de verificación reglada, es decir, le compete exclusivamente comprobar si los documentos que se le presentan corresponden a materia objeto del Registro y si reúnen los requisitos formales necesarios. 
Añade el Tribunal Supremo que lo anterior se ve confirmado por la LO 1/2002. Así, dicha LO dice en su Exposición de Motivos que la Constitución eliminó el sistema de control preventivo, contenido en la Ley 191/1964, de 24 de diciembre ; que la Ley, en lo que hace al funcionamiento de las asociaciones, protege su capacidad para no sufrir interferencia alguna de las Administraciones, como tan rotundamente plasma el apartado 4 del artículo 22 de la Constitución, salvo la que pudiera venir determinada por la concurrencia de otros valores, derechos o libertades constitucionales que deban ser objeto de protección al mismo tiempo y nivel que el derecho de asociación; o que del contenido del artículo 22.3 de la Constitución se deriva que la Administración carece, al gestionar los Registros, de facultades que pudieran entrañar un control material de legalización o reconocimiento.

El TS recuerda también que en el articulado de la LO se establece que la Administración no podrá adoptar medidas preventivas o suspensivas que interfieran en la vida interna de las asociaciones (artículo 4.2); que la Administración procederá a la inscripción, limitando su actividad a la verificación del cumplimiento de los requisitos que han de reunir el acta fundacional y los Estatutos (artículo 30.1, párrafo tercero); atribuyendo al orden jurisdiccional civil (artículo 40) el conocimiento de las impugnaciones que tanto los asociados como terceros legitimados puedan deducir contra los acuerdos y actuaciones de las asociaciones, sin que la existencia de la impugnación obstaculice la publicidad registral, ya que (artículo 40.4) en tanto se resuelven las contiendas de orden interno que puedan suscitarse en las asociaciones, las solicitudes de constancia registral que se formulen sobre las cuestiones controvertidas sólo darán lugar a anotaciones provisionales.

La lógica jurídica de la Sala de lo Contencioso del Tribunal Supremo en esta Sentencia es meridianamente clara, y ha sido mantenida en sendas Sentencias que transcriben su contenido, STS de 30 de diciembre de 2004 y de 25 de enero de 2005. Por lo tanto, es jurisprudencia consolidada del Tribunal Supremo que el Registro de Asociaciones no puede denegar la inscripción de actos inscribibles por cuestiones de fondo.

\section{Posibles consecuencias de la inscripción de un acto contrario a derecho}

Si el Registro de Asociaciones no puede denegar la inscripción de un acto si se cumplen los requisitos formales de la petición ni legalmente forzar a que se modifique su contenido, podría por tanto ocurrir que se solicitara la inscripción registral de un acto manifiestamente contrario a Derecho y no hubiera ninguna forma de evitar su plena incorporación al tráfico 
jurídico, motivo esgrimido en repetidas ocasiones por el registro de asociaciones para realizar dicho con el control anteriormente descrito y cuya ilegalidad ya has ido expuesta.

En Derecho de Asociaciones, por su naturaleza, no existe el control preventivo de legalidad que existe en Derecho de Sociedades, que tan gráficamente resume Cabanas Trejo «allí donde la escritura sea el titulo formal habilitante de la inscripción, al control registral precede al del notario, y será el único cuando falte aquel, [...] y ese control solo tiene una manera de manifestarse en la práctica: mediante la negativa del notario a la autorización si los requisitos legales no se han cumplido" (Cabanas Trejo, 193).

Esto debe analizarse desde una triple óptica: primero, debe examinarse las consecuencias que tiene la adopción de dicho acto antijurídico; segundo, qué consecuencias tendrá el hecho de su inscripción; tercero, qué medidas puede adoptar la Administración para evitar la incorporación al tráfico jurídico de un acto contrario a Derecho.

En referencia a las consecuencias de la adopción de un acto antijurídico, habrá que distinguir la naturaleza de dicha antijuridicidad: si son contrarios a la Ley o si son contrarios a los Estatutos.

Los actos contrarios a los artículos imperativos de la LODA o a la Ley de Asociaciones, o a cualquier otra norma imperativa serán nulos (ex art. $6.3 \mathrm{CC}$ ) por lo que no podrán causar ningún efecto y podrán ser impugnados en cualquier momento por cualquier persona que acredite un interés legítimo (art. 40.2. ${ }^{\circ}$ LODA).

En cambio, los actos contrarios a los Estatutos serán anulables, pudiendo cualquier asociado impugnar los acuerdos en un plazo de cuarenta días de su adopción (art. 40.3. ${ }^{\circ}$ LODA). Esto es así porque, conforme al derecho de autoorganización, la Asociación puede apartarse conscientemente de sus propios Estatutos y adoptar, en un caso concreto, una decisión que resulte más conveniente a sus intereses; ahora bien, bastará que uno solo de los asociados no esté de acuerdo con esa decisión contraria a los Estatutos para que se pueda impugnar dicho acuerdo ante la jurisdicción civil y esta pueda entrar a valorar su juridicidad, valoración que tal y como dice la Sala de lo Civil del Tribunal Supremo en Sentencia 178/2018 de 3 de abril, no solo no infringirá el principio de autoorganización, sino que lo protegerá: es la propia Asociación la que se ha dotado en sus estatutos de una estructura en la que los asociados participan en la adopción de sus decisiones fundamentales, y en principio debe respetar dicha estructura. Transcurrido el plazo de los 40 días, la acción caducará y el acto será inatacable.

En este sentido, compartimos plenamente las criticas que realiza Pérez Escalona (2007. 337 y ss) sobre la falta de distinción en la LODA entre 
las causas para la impugnación de los acuerdos sociales, en especial aquella en la que recuerda que aun cuando la consecuencia jurídica del incumplimiento de una norma legal sea la nulidad total e imprescriptible del acuerdo que la haya incumplido, se crea "una inseguridad jurídica difícilmente conciliable con la necesidad de certeza que demanda la protección del tráfico en el funcionamiento de la entidad».

Respecto a los efectos de la inscripción registral de un acto nulo o anulable, debemos recordar que la inscripción tiene meros efectos de publicidad, sin que, en principio, el hecho de la inscripción le otorgue ninguna presunción de validez jurídica a ese acuerdo, más allá de la limitación de la responsabilidad y de la oponibilidad a terceros. En palabras de Cabanas Trejo, hablando del Registro Mercantil pero cuyas reflexiones son totalmente extrapolables al Registro de Asociaciones «nos basta simplemente con poner de manifiesto que los efectos del Registro Mercantil, aunque sin ninguna duda son de gran importancia, tampoco deben exagerarse, pues llegan hasta donde pueden llegar, pero no más lejos, y por esa misma razón los controles de acceso tampoco deberían extremarse. Otros autores prefieren llegar al mismo resultado, pero siguiendo un recorrido inverso, y así, tras poner de manifiesto las debilidades endémicas de la calificación registral en contraste con la actividad jurisdiccional, entienden que son los efectos legitimadores los que deben matizarse» (Cabanas Trejo, 219).

Por lo tanto, tanto la adopción de un acto contrario a Derecho como la inscripción de dicho acto en el Registro de Asociaciones tienen consecuencias que distan mucho de ser problemas irresolubles jurídicamente.

Lege ferenda: un posible mecanismo del registro de asociaciones para fomentar el cumplimiento del derecho de asociación y la seguridad jurídica

Está por tanto meridianamente claro que el registro de asociaciones no puede, al recibir una solicitud de inscripción que pueda estimarse que vulnera el derecho de asociación, requerir subsanar la solicitud en el sentido de modificar el contenido del acto para entender cumplida esa norma, ni tampoco denegar la inscripción; y también que, además, la inscripción de dicho acto no genera consecuencias jurídicas difícilmente resolubles. Ello no obstante, no hay duda de que la inscripción genera una apariencia de que dicho acto es acorde a derecho, lo cual crea una situación de inseguridad jurídica que el Estado tratar de evitar.

En estos casos, consideramos que existe un marco legal más que consistente que legitime al Registro de Asociaciones a habilitar y activar un sistema que evite este tipo de situaciones, advirtiendo a los que soliciten la inscripción de los posibles vicios de legalidad que se observen en ellas: por un 
lado, el art. 41 de la Ley Vasca de Asociaciones, que establece un mandato de las administraciones públicas del País Vasco de fomentar el asociacionismo, por otro, el art. 53. f) de la Ley 39/2015, que establece que los interesados en un procedimiento administrativo tienen derecho a obtener información y orientación acerca de los requisitos jurídicos o técnicos que las disposiciones vigentes impongan a los proyectos, actuaciones o solicitudes que se propongan realizar, y más en concreto el art. 4.4 de la LODA que establece que la Administración competente ofrecerá el asesoramiento y la información técnica de que disponga, cuando sea solicitada, por quienes acometan proyectos asociativos de interés general, y el art. 3.5 del Reglamento del Registro General de Asociaciones del País Vasco que establece como función del Registro la de asesorar e informar a las asociaciones en todo lo relacionado con las inscripciones que se practiquen en el Registro.

En efecto, cuando alguien presenta una solicitud de inscripción en el Registro que adolezca de graves defectos legales no resulta muy alambicado entender que esa persona necesita de asesoramiento o información sobre los requisitos jurídicos del acto en cuestión, y que prestarle dicho asesoramiento redundará en beneficio del asociacionismo.

Por tanto, y como propuesta de lege ferenda, sugerimos que por vía de Reglamento del Registro General de Asociaciones del País Vasco se introduzca un mecanismo por el cual, cuando un funcionario del Registro de Asociaciones reciba una solicitud de inscripción de un acto que podría ser jurídicamente irregular, se lo haga saber al interesado y en su caso le sugiera la forma de sanear dichos defectos, procediendo ello no obstante a la inscripción solicitada, dejando constancia registral de dicha advertencia a los efectos que pudiera tener en relación a la limitación de la responsabilidad y la oponibilidad a terceros, del mismo modo que se realiza ahora un asiento de anotación provisional para la constancia registral que se formule sobre contiendas de orden interno.

De esta manera, se cohonestaría la función de mera publicidad registral, respetuosa con el principio de autoorganización con la protección de la seguridad jurídica necesaria para el fomento del asociacionismo en el País Vasco.

\section{Bibliografía}

Bermejo Vera, J. (1995). La dimensión constitucional del Derecho de Asociación. Revista de Administración Pública n.o 136, enero-abril 1995.

Cabanas Trejo, R. (2009). Inscripción y personalidad jurídica: (una lectura mercantil a la luz de la Constitución y la legislación de asociaciones). Consejo General del Notariado. 
Gómez Montoro, A. (2004). Asociación, Constitución, Ley: Sobre el contenido Constitucional del derecho de asociación. Centro de Estudios Políticos y Constitucionales, col. Premio Tomás y Valiente. Madrid.

González Perez, J.; Fernández Farreres, G. (2002). Derecho de Asociación. Comentarios a la Ley Orgánica 1/2002, de 22 de marzo. Civitas. Madrid.

Iribarren, M. (2018). Pactos parasociales y cambios de socios (una versión dinámica de los pactos parasociales). Revista de Derecho de Sociedades 53 mayo-agosto 2018, págs. 79-108.

Lucas Murillo de la Cueva, E. (1996). El Derecho de Asociación. Tecnos. Madrid.

Marín Gómez, I. El derecho de asociación en la España contemporánea. Estudio de la ley de asociaciones de 1964 y los efectos de su procedimiento registral en el franquismo. Revista Aranzadi Doctrinal núm. 1/2016.

Pérez Escalona, S. (2007). El Derecho de Asociación y las Asociaciones en el Sistema Constitucional Español. Aranzadi. Cizur Menor.

Rego Blanco, M. a D. (2017). "La presentación de solicitudes, escritos y documentos ante las administraciones públicas» en Tratado de Procedimiento Administrativo Común y Régimen Jurídico básico del Sector Público (Dir. Eduardo Gamero Casado). Tirant lo Blanch. Valencia.

Zambonino Pulito, M (2018). El deber de la Administración de no resolver materialmente el procedimiento. Tirant Lo Blanch. Valencia.

\section{Jurisprudencia}

Sentencia del Tribunal Supremo, Sala de lo Contencioso-Administrativo, de 8 de junio de 2004.

Sentencia del Tribunal Supremo, Sala de lo Contencioso-Administrativo, de 30 de diciembre de 2004.

Sentencia del Tribunal Supremo, Sala de lo Contencioso-Administrativo, de 25 de enero de 2005.

Sentencia del Tribunal Supremo, Sala de lo Civil, de 3 de abril de 2018.

Sentencia del Tribunal Constitucional de 25 de junio de 1986. 



\title{
Neoliberalismoari aurre egingo dion Berrikuntza Sozial eraldatzailea
}

\author{
Transformative Social Innovation capable \\ to get over the present neoliberal stage \\ Eusebio Lasa Altuna
}

Universidad del País Vasco/Euskal Herriko Unibertsitatea (UPV/EHU) GEZKI institutuko kidea

\begin{abstract}
Laburpena: Artikulu honetan neoliberalismoari aurre egingo dion Berrikuntza Sozial Eraldatzailearen kontzeptua finkatu nahi da. Berrikuntza Soziala ulertzeko modu asko daudenez artikulu honen helburua Berrikuntza Soziala gizarte-eraldaketaren alde ipintzea izango da. Berrikuntza Sozial Eraldatzailearen kontzeptua aztertzen denean ezinbestekoa ikusten da errotikako iraulketa bat ematea, kapitalismoarekin haustura bat burutzea, izaeran, bitartekoetan eta antolaketa moduan. Horregatik, artikulu honen asmoa da gizarte-eraldaketan oinarritutako Berrikuntza Sozial Eraldatzailearen zimenduak antolatzea neoliberalismoaren gaurko fasea zalantzan jartzeko eta gizarteari bide berriak irekitzen joateko.
\end{abstract}

Hitz gakoak: Berrikuntza Sozial Eraldatzailea, Garapen Eredu Alternatiboa, Ekonomia Sozial eta Solidarioa.

\begin{abstract}
In this article we want to set up the concept of Transformative Social Innovation capable to get over the present neoliberal stage. As there are many different ways to understand Social Innovation the aim of this article is to use Social Innovation for social transformation. When we talk about Transformative Social Innovation it is necessary a radical change, a breakup with capitalist system in nature, means and organization. Therefore, the intention of this article is to establish the rules for Transformative Social Innovation based on social transformation in order to reconsider the present neoliberal stage and, at the same time, open new ways for society.
\end{abstract}

Keywords: Transformative Social Innovation, Alternative Social Model, Social and Solidarity Economy.

Econlit gakoak: A13, B55, F60, L31, O35, P13

* Harremanetan jartzeko/Corresponding author: Eusebio Lasa Altuna. GEZKI institutu. Universidad del País Vasco/Euskal Herriko Unibertsitatea (UPV/EHU) - eusebio.lasa@ehu.eus

Nola aipatu/How to cite: Lasa Altuna, Eusebio (2019). "Neoliberalismoari aurre egingo dion Berrikuntza Sozial eraldatzailea» GizarteEkonomiarenEuskalAldizkaria/RevistaVascadeEconomíaSocial,16,49-67.(https://doi.org/10.1387/reves.21218).

Jasoa: 13 maiatza, 2019; onartua: 27 abuztua, 2019.

ISSN 1698-7446 - elSSN 2444-3107 / (c) 2019 UPV/EHU 


\section{Sarrera}

Artikulu honen helburua Berrikuntza Sozial Eraldatzailearen terminoaren inguruan teorizatzea da, bereziki eredu neoliberalari aurre egiteko tresna eraginkorra bihurtzeko. Gaur egungo gizartea aztertzen badugu konturatzen gara kapitalismoak desberdintasun sozioekonomiko izugarriak sortzen dituela ez bakarrik munduko biztanleriaren artean, baita ere Europar Batasunaren barruan (Duñaiturria, 2007). Krisi hori ez da bakarrik ekonomikoa. Baita ere soziala, kulturala, politikoa, ekologikoa, ideologikoa eta etikoa. Azken finean, zibilizazioaren paradigma bera krisian dago. Mundua ez dago aldaketen garai baten aurrean bakarrik, aro aldaketa sakon baten ataria gurutzatzen ari da (Mendizabal, 2012). Kapitalismoaren garaipen ideologikoak bere krisi sakona ezkutatzen du ez delako gai gizakiaren etorkizunak planteatzen dituen erronkei, arazoei eta zalantzei erantzuteko. Horregatik adierazi daiteke gaur egungo eredu neoliberalak huts egin duela. Hala ere, jauzia ez da egun batetik bestera emango. Sistema kapitalistak gaitasuna dauka erreproduzitzeko egoera honetaz probetxua ateratzen duten klase sozialak eta interes ekonomikoak daudelako (Peck, 2013). Testuinguru honetan, egunetik egunera garrantzitsuagoa da beste gizarte-eredu bat eraikitzea balio eta politika desberdinekin, elkarkidetasunean, ondasunaren banaketan, parte hartze sozialean eta bizi kalitatean oinarrituta. Horregatik, ezinbestekoa da apustu bat egitea beste garapen eredu baten alde, beste gizarte baten alde.

Hala ere, jakitun gara ez dela lan erraza izango neoliberalismoa garaitzea baino bai ezinbestekoa gaur egungo eredu ekonomiko nagusiak dakarren dualizazioa eta injustizia gainditzeko (Klein, 2013). Bide luze eta aldapatsu hori egiteko artikulu honetan garatzen dugun Berrikuntza Sozial Eraldatzailea tresna egokia izan daiteke helburu hori lortzeko. Hala ere artikulu honen helburua izango da Berrikuntza Soziala gizarte-eraldaketaren alde ipintzea. Hain zuzen ere, Berrikuntza Soziala ulertzeko modu asko daude. Autore batzuk pentsatzen dute Berrikuntza Sozialari buruz hitz egiteko nahikoa dela praktika zahar bat egokitzea, ideia bat beste testuinguru batean aplikatzea edo bazterketa sozialari aurre egiteko edozein neurri hartzea. Ez hori bakarrik, Berrikuntza Sozial Eraldatzailea terminoa erabili duten zenbait autore eta proiektuek ere maila mikroko dinamikak eta aldaketak proposatzen dituzte eraldaketaren aldeko teoria sendo bat antolatu gabe. TRANSIT (2018) proiektua horren adibide esanguratsua izan daiteke. Zenbait autoreentzat proiektu horretan erabiltzen den Berrikuntza Sozial Eraldatzailea ez da nahikoa gaur egungo egitura politikoa eta ekonomikoa gainditzeko. Novy-ren (2017) arabera TRANSIT proiektuak ez du Berrikuntza Soziala sistemaren eraldaketaren mesedera jarri. TRANSIT programak aplikatu duen Berrikuntza Soziala, benetako eraldaketa sakona 
bultzatzea baino, gehiago aritu da neoliberalismoaren korronte nagusiaren barruan mikro aldaketak burutzen.

Artikulu honetan Berrikuntza Sozial Eraldatzailearen kontzeptua aztertzen denean ezinbestekoa ikusten da errotikako iraulketa bat ematea, kapitalismoarekin haustura bat burutzea, izaeran, bitartekoetan eta antolaketa moduan. Horregatik, artikulu honen asmoa da gizarte-eraldaketan oinarritutako Berrikuntza Sozial Eraldatzailearen zimenduak antolatzea neoliberalismoaren gaurko fasea zalantzan jartzeko eta gizarteari bide berriak irekitzen joateko.

Helburu hori betetzeko artikulu honek hurrengo egitura dauka: lehenbiziko atalean Berrikuntza Sozialaren kontzeptuaren hastapena azpimarratuko da. Gero guk garatu nahi dugun Berrikuntza Sozialaren kontzeptuari emango zaio garrantzia. Ondoren, artikulu honetan garatzen den Berrikuntza Sozial Eraldatzailearen giltzarri nagusiak aurkeztuko dira. Azkeneko atalean, berriz, zenbait ondorio aterako dira.

\section{Berrikuntza Sozialaren kontzeptuaren hastapenak}

Berrikuntza Soziala gaurkotasuna duen kontzeptua da. Literatura asko idatzi da Berrikuntza Sozialari buruz. Berrikuntza Sozialaren terminoa arrazoi desberdinengatik eta testuinguru desberdinetan plazaratu da. Berrikuntza Sozialaren kontzeptua lehenbizi soziologoek erabili zuten XIX. mendearen amaieran eta Xx. mendearen hasieran (Ayob, Teasdale eta Fagan, 2016), alde batetik, sarean antolatutako gizarteek nola suspertzen zuten berrikuntza teknologikoa azaltzeko (Tarde, 1899) eta, bestetik, berrikuntzen eragin soziala ulertzeko (Hoggan, 1909).

Bestalde, Berrikuntza Sozialaren kontzeptua 60. eta 70. hamarkadan ikasle eta langile mugimenduak erabili zuten Paris, Berlin eta Europa eta Ameriketako hiriburu desberdinetan (Moulaert, MacCallum eta Hillier, 2013). Izendatzaile komun hori beti gorako ekonomia eta gizarte dinamika parte hartzaileak eta kreatzaileak sortuko zituzten ekimen kolektibo eta eraldaketa sozial desberdinak aipatzeko erabili zen (Chambon, David eta Devevey, 1982). Garai horretan ikasle eta langileriaren demokrazia, generoa eta burujabetzari buruzko eztabaida publikoak gaurkotasun handia zuten.

Baita ere, Berrikuntza Sozialaren terminoa erabiliko da kudeaketa lanetan egituren murriztapenak eta giza sinergiak lortzeko prozesuen beharra azpimarratzeko (Drucker,1987). Termino horrekin adierazi nahi zen gizarte batek ipini behar zituen bitartekoak enpresetan eta gobernuetan zegoen burokrazia astuna arintzeko. Garai berriagotan diskurtso hori alde batera utzi da New $\mathrm{Pu}$ blic Management (NPM) metodoen aldeko estiloak eta ereduak bultzatzeko.

Ayob et al.-ek (2016) azterketa bibliometrikoa erabili dute Berrikuntza Sozialaren kontzeptualizazio desberdinak sailkatzeko. Bertatik atera den 
ondorio nagusiena da Berrikuntza Sozialaren literatura sailkatu daitekeela hiru gai nagusien inguruan: berrikuntza teknologikoa, gizarte-harremanak eta gizartean sortutako eraginak kontuan hartuta. 1989tik aurrera argitaratutako argitalpenak sailkatu daitezke gai horien lau konbinaketa desberdinen arabera: gizarte harremanak, gizartean eraginak, gizarte harremanak eta gizartean eraginak, eta gizarte harremanak eta berrikuntza teknologikoak. Gainera, 1999 urtea baino lehen ez dago patroi argi bat Berrikuntza Sozialaren kontzeptua zehazteko garaian. Literatura zientifiko gehiena gizarte harremanen ikuspegi soziologiko batetik dator eta gutxieneko argitalpenak, berriz, berrikuntza teknologikoarekin lotzen dira. 2000. urtera itxaron beharko da Berrikuntza Sozialaren kontzeptuaren atzean gizarte-aldaketak eragingo dituen gizarte harremanen forma berriak azalarazteko. Ordutik aurrera, nahiz eta Berrikuntza Sozialaren azken ikuskera hori gailenduko den, gutxieneko literatura batek jarraituko du aldaketa teknologikoari garrantzia ematen.

Gainera, Ayob et al.-ek (2016) Berrikuntza Sozialaren kontzeptu zabal hori hiru proposamen zehatzetara mugatzen dute. Lehenbiziko proposamenak, literatura soziologikotik eratorrita baina baita ere teknologia eta gizarte aldaketan, zientzia politikoan eta pentsamenduaren diseinuaren literaturan presente dagoena, Berrikuntza Sozialaren kontzeptuak elkarlanerako forma berrien aplikazioa dakar, norbanakoen edo erakundeen artean, eta sarritan gobernuaren, gizarte zibilaren eta hiritarren arteko harremanak berritzea eta horizontalagoak bihurtzea eskatzen du. Bigarren proposamena, teknologia eta aldaketa sozialen literaturatik eta zientzia politikotik datorrena, Berrikuntza Sozial horiek gizarte eta botere harreman berri batetara eraman gaitzake. Azkenik, hirugarren proposamenak, enpresa-administrazioan eta kudeaketa-literaturan agertzen dena, berrikuntzak ikuspegi funtzionaletik gizartean eragin positiboa eduki behar duela defendatzen du, bizi kalitatea eta kantitatea handituz (Pol eta Ville, 2009).

\section{1. taula}

Berrikuntza Sozialaren hiru proposamen zehatz

\begin{tabular}{c|l}
\hline Lehen proposamena & Elkarlanerako forma berrien aplikazioa dakar \\
\hline Bigarren proposamena & Gizarte eta botere harreman berri batera garamatza \\
\hline Hirugarren proposamena & $\begin{array}{l}\text { Enpresa-administrazioan eta kudeaketan garatzen da eta } \\
\text { gizartean eragin positiboa eduki behar du, bizi kalitatea } \\
\text { eta kantitatea handituz }\end{array}$ \\
\hline
\end{tabular}

Iturria: Ayob et al. (2016) ikerketatik ateratako datuekin geuk egina. 


\section{Garatu nahi dugun Berrikuntza Sozialaren kontzeptua}

Berrikuntza Sozialaren ikuspegi eta eskema zabal horren barruan interes berezia jarri dugu erakundeen gobernantzan eta funtzionamendu demokratikoan. Baita ere, gizabanakoen inbertsioen ordainsarietan baino gehiago ongizate kolektiboan zentratu da gure atentzioa. Aldi berean, gure hausnarketari gizarte mugimenduaren ikuspegia txertatu nahi izan diogu momentuko gizarte-arauak auzian jarriz eta gizarte-ordena berria aldarrikatuz. Horregatik artikulu honetan bereziki Quebec-eko eta Europako autoreetan oinarritu gara. Hau da, hurbilketa anglosaxoia alda batera utzi dugu eta bereziki korronte frankofonoko autoreak aukeratu ditugu.

Gainera, Berrikuntza Soziala zehazteko garaian tradizio erradikalean eta normatiboan zimenduak jarri ditugu. Bertan, aldaketa soziala (eta politikoa) gizarte-erlazioen berrikuntzaren ondorio bezala ikusten da. Tradizio erradikala, Berrikuntza Sozial indartsua daramana, koprodukziotik oso gertu dago. Gainera, koprodukzio hori lankidetzan, ideia berrien sorkuntzan, ahalduntzean eta gizartearen eraldaketan sostengatzen da (Bovaird eta Loeffler, 2012; Brandsen eta Pestoff, 2006).

Guk landuko dugun Berrikuntza Sozialaren ikuskera hori asko zabaldu da neoliberalismoaren hazkunde-ereduak sendotasunik erakutsi ez duelako (Klein, 2013). Eredu neoliberalaren krisiak eragile sozialak behartzen ditu arazo sozial nagusiei erantzun bat aurkitzera, hau da, berrikuntza bultzatzera.

Bide hori jarraituz Berrikuntza Sozialera Kleinek (2013) proposatutako hiru ikuspegi desberdinetatik gerturatuko gara. Alde batetik, Ikuspegi epistemologikoa daukagu. Hurbilketa alternatibo honek Berrikuntza Soziala paradigma aldaketa baten parte kontsideratzen du. Ezagupena koeraikuntzaren emaitza da, ikertzaileen eta aktore desberdinen elkarlanerako ahaleginaren emaitza izango da faktore lokalak eta globalak kontuan hartuz. Bestetik, Ikuspegi etikoa garatzen da. Zentzu etikoa kontuan hartzen bada Berrikuntza Sozialak elkarrekin ikasteko bitarteko bat bezala eta pertsona hauskorren bizi baldintzak hobetzeko gaitasunak handitzeko tresna moduan funtzionatzen du. Aldi berean, ikuspegi etikoak ere gizarte-segmentu hori prekarietatean mantentzen duen ingurumen instituzionala eraldatzeko bitartekoak hobetzen ditu. Azkenik, Ikuspegi estrategikoa aztertzen bada Berrikuntza Soziala proiektu integratzaile baten gidaria bihurtzen da ongizatea sortu eta banatzeko Komunitateko aktore politiko, sozial eta ekologikoek osatutako sare bati esker. Horretarako ezinbestekoa da alde batetik, maila globala, nazionala eta lokala batzea eta bestetik, giza jardueraren atal desberdinak koordinatzea, besteak beste, arlo publikoa, soziala eta pribatua. 


\section{1. taula}

Berrikuntza Sozialera gerturatzeko hiru ikuspegi

\begin{tabular}{|c|c|c|}
\hline Epistemologikoa & Etikoa & Estrategikoa \\
\hline $\begin{array}{l}\text { Berrikuntza Soziala: para- } \\
\text { digma aldaketa baten on- } \\
\text { dorioa. }\end{array}$ & $\begin{array}{l}\text { Berrikuntza Soziala: } \\
\text { 1. Elkarrekin ikasteko bi- } \\
\text { tarteko bat. }\end{array}$ & $\begin{array}{l}\text { Berrikuntza Soziala: } \\
\text { proiektu integratzaile baten } \\
\text { gidaria. }\end{array}$ \\
\hline $\begin{array}{l}\text { - Ezagupena ikertzaileen } \\
\text { eta aktore desberdinen } \\
\text { elkarlanerako ahalegina- } \\
\text { ren emaitza da: Koerai- } \\
\text { kuntzaren ondorioa. } \\
\text { — Faktore lokalak eta glo- } \\
\text { balak Kontuan hartu } \\
\text { beharko dira. }\end{array}$ & $\begin{array}{l}\text { 2. Pertsona hauskorren } \\
\text { bizi baldintzak hobe- } \\
\text { tzeko gaitasunak han- } \\
\text { ditzeko tresna. } \\
\text { _ Prekarietatea sor- } \\
\text { tzen duen Inguru- } \\
\text { men instituzionala } \\
\text { eraldatzeko bitarte- } \\
\text { koak hobetzen ditu. }\end{array}$ & $\begin{array}{l}\text { - Maila globala, nazionala } \\
\text { eta lokala batu behar da. } \\
\text { _ Giza jardueraren atal } \\
\text { desberdinak (arlo publi- } \\
\text { koa, soziala eta pribatua) } \\
\text { koordinatzea eskatzen } \\
\text { du. }\end{array}$ \\
\hline
\end{tabular}

Iturria: Kleinen (2015) datuekin geuk egina.

Aldi berean, 80. hamarkadatik aurrera garatu diren aldaketa sozialaren kontzepzio estuak eta deterministak zalantzan jarriko ditugu (Hillenkamp, 2016). Garai horretan Hirugarren Mundua bezala ezagutzen zen eremuko kanpo-zorren krisiaren ondorioz berriztatze ekonomikoko estatu-politikak zaharkituta gelditzen dira eta, aldi berean, Brundtland (1987) txostenak krisi ekologikoaren eskala handiko kontzientzia hartzera laguntzen du. Doktrina neoliberalaren aurkako jarrerak alde batetik gizarte zibilaren indarketa dakar eta bestetik aldaketaren motor bezala norbanakoen eta Garapenerako Gobernuz Kanpoko Erakundeen papera sendotuta ateratzen da.

Ikuspegi horri Bouchard-ek (2013) garatu duen Berrikuntza Sozialaren prozesuen eta produktuen izaera kolektiboa gehituko diogu. Gerturatze horretan, nahiz eta mikrosistemak uniformetasun sozial berriekin esperimentatzeko eremuak badiren ere, berrikuntza ez da ekimen arrazional eta borondatezko batetik bakarrik sortzen. Kasu honetan Berrikuntza Soziala egiturazko geldialdiak gizarte-mugimenduen ekimenekin lotuz garatzen da. Krisi garaietan, arau makro-sozialek (merkatua, estatua, negoziazio kolektiboa) astindu ederra jasotzen dute toki gehiago eginez berrikuntzarako eta esperimentaziorako. Lidergoa duten eragile sozialengatik eta tokian tokiko esperimentuetatik sortutako erregulazio berriak gero gizarte osora zabalduko dira.

Hurbilketa honetan Berrikuntza Sozialaren definizio zabalduenetakoa Quebeceko CRISES (Centre de Recherche sur les Innovations Sociales) 
erakundearena da: «Berrikuntza Soziala eragile sozialek martxan ipini duten esku-hartze bat da helburu bati erantzuteko, behar zehatzak betetzeko, irtenbide bat eskaintzeko edo aukera batez baliatu ekimenerako giza harremanak aldatzeko, ekintzarako esparrua eraldatzeko edo kultura-norabide berriak proposatzeko» (Bouchard, 2013). CRISESen definizio hori hobeto ulertzen da esanez Berrikuntza Soziala behar zehatzei emandako erantzun bat dela baino baita ere Berrikuntza Sozialak aldaketa soziala bultzatzen duela ikuspegi berri baten bitartez arazoak ikusi eta definitzeko eta bidez batez arazo horiei irtenbideak aurkitzeko (Lévesque, 2006).

Berrikuntza Sozialaren definizio horri Moulaert et al.-eren (2013) hausnarketa gehituko diogu. Azken autore horiek azpimarratzen dute Berrikuntza Sozialari buruz hitz egiten dutenean irtenbide aurrerakoiak bilatzen ari direla besteak beste bazterketa, eskasia, alienazioa eta ongizate faltari aurre egiteko. Hau da, aurrerapen soziala eta garapena bultzatzeko tresna bezala identifikatzen dute. Horregatik, Moulaert et al.-entzat (2013) Berrikuntza Sozialaren eginkizun nagusi bat bazterketa eta behar egoerei era egokian erantzuteko ekimen kolektibo eta eraldaketa sozial mota desberdinak definitzea da. Berrikuntza Sozialarekin anbizio politiko-ideologikoa martxan ipini nahi da teoria horiek aplikatuz eta garapen politiketan nagusi izan diren teknologian eta negozioan oinarritutako diskurtsoei alternatiba bat eskainiz. Hain zuzen ere, Moulaert et al.-ek (2013) Berrikuntza Soziala ikuspegi epistemologiko batetik aztertzen dute arlo politiko eta sozialari garrantzia emanez eta garapen alternatiborako estrategia bateko osagai nagusi bat bezala aldarrikatuz. Berrikuntza Soziala aurkezten dute askotariko disziplinen arteko ikerketaren ardatz eragile moduan eta aldi berean jarduera kolektiboaren gidari.

Aldi berean, Bouchard (2007) eta Richez-Battesti, Petrella eta Valladeri (2012) jarraituz, ekonomia sozial eta solidarioa Berrikuntza Sozial horren motorra bihurtuko da. Alde batetik, Berrikuntza Sozialaren ikuspegi funtzionalagoa hartzen badugu, ekonomia soziala saiatzen da estatuak edo merkatuak betetzen ez dituen beharrak estaltzen. Bestetik, Berrikuntza Sozialaren ikuspegi eraldatzaileagoa aplikatzen badugu, ekonomia sozialak borroka sozialekin batera behar ekonomiko eta sozialei erantzuteko modu berriak asmatuko ditu, tokian tokiko arauak eta instituzioak goitik behera irauliz. Ekonomia sozialak Berrikuntza Sozial iraunkorrak eragiten ditu, antolaketa maila gainditu eta esparru instituzionala ukitu ondoren gaur egungo eredu ekonomikoari alternatiba bat bilatzen dio (Bouchard, 2006).

Horrekin batera, Berrikuntza Sozialaren oinarri honi, ikuspegi instituzionalagoa garatzen duten ekarpenak erantsiko dizkiogu. Hau da, alde batetik, gizartea eraldatzeko praktika berriak, arauak eta erregelak azpimarratuko dira. Eta bestetik, testuinguru instituzionalari eta lokalari garrantzia emango zaio. Ikuspegi horrek atentzio berezia jarriko du lurraldean sor- 
tuko diren prozesu kolektiboetan asegabeko behar sozialak betetzeko, beti ere, gizartea eraldatzeko dinamika baten barruan.

Gainera, Berrikuntza Sozialaren bitartez eraiki nahi den eredu berri hori koherentea izan behar da globalizazioak ekarri dituen sozietate konfigurazio berriekin baina aldi berean hiritarrei eman behar die aitorpena eta ahalmen erreala beren eskubideak eta ardurak gauzatzeko (Lévesque, 2011). Zalantzarik gabe, gaur egungo globalizazio prozesua ikus daiteke batera bizitzeko dinamika inklusibo, solidario eta ekologiko baten aldeko aukera historiko bat bezala. Ikuspegi hori guztiz txertatuta dago hiritarren mugimenduen aldarrikapenekin (Klein eta Harrisson, 2010). Ekimen kolektibo berri horiek erabiliz sortuko dira berrikuntza sozialak han eta hemen, gobernamendu arloan, finantzetan, ingurumenaren babesaren atalean, pobreziaren kontrako borrokan, kulturan, gizarteratze politiketan, ea. (Klein et al., 2010).

Berrikuntza horiek estrategia politiko, ekonomiko, sozial eta ekologiko global baten erreferenteak bihurtu behar dira eta eragina eduki beharko dute Estatuan, kapital pribatuan eta gizarte zibileko aktoreetan ez bada nahi eredu kapitalistak berrikuntza horiek erabiltzea bere makinariaren eraginkortasuna handitzeko (Peck, 2013). Hain zuzen ere, Berrikuntza Soziala eraldaketa soziala bilatzen duten mugimendu sozial eta politikoentzat erreferentzia-puntu garrantzitsua bihurtzen ari da. Baino bestetik, Berrikuntza Soziala erabiltzen ari da kapitalismoaren hurbilketa berri bat bultzatzeko, hots, ongizate-estatuaren krisiaren testuinguruan ekonomia sozial «merkearen» bitartez lanpostu berriak sortzeko eta zerbitzuak pribatizatzeko.

\section{Berrikuntza Soziala «eraldatzailea» izan behar du}

Artikulu honetan egin ditugun hausnarketak ikusita ondorioztatu dezakegu gaur egun erronka bat dela Berrikuntza Soziala gizarte-eraldaketa proiektu baten alde ipintzea. Hain zuzen ere, Berrikuntza Soziala ulertzeko modu asko daudela ikusi dugu. Autore batzuk pentsatzen dute berrikuntzari buruz hitz egiteko nahikoa dela praktika zahar bat egokitzea, ideia bat beste testuinguru batean aplikatzea edo bazterketa sozialari aurre egiteko edozein neurri hartzea. Beste batzuk, berriz, ezinbestekoa ikusten dute errotikako iraulketa bat ematea, haustura bat burutzea, izaeran, bitartekoetan eta antolaketa moduan. Horregatik, argi gelditu da Berrikuntza Sozialaren hitzarekin nahasketa handia sortzen dela Berrikuntza Sozial mota guzti horiek esanahi berdin baten azpian biltzen direlako eta bide batez eraldaketa sozial erreal baten aldeko Berrikuntza Sozialak zurrunbilo horren barruan galduta eta urardotuta agertzeko arriskua dagoelako. Hori dela eta artikulu honen 2. atalean gure asmoa izan da guk garatu nahi du- 
gun Berrikuntza Sozialaren kontzeptuaren oinarriak ondo finkatuta uztea benetako eraldaketaren bidea marrazteko.

Bestalde, azpimarratu nahi dugu ere Berrikuntza Sozial Eraldatzailea terminoa erabili duten zenbait autore eta proiektuek tamaina txikiko aldakuntzak planteatu dituztela eraldaketaren aldeko teoria osatu bat antolatu gabe. TRANSIT (2018) proiektua horren adibide esanguratsua izan daiteke. Egitasmo hori esplizituki Berrikuntza Sozial Eraldatzailearen teoria aztertzeko jaio ondoren bere asmoa aldaketa sakonak burutzea zen. Ikerketaren diseinuan TRANSIT-ek (2018) hiru makro-dinamika ukitu ditu: krisi ekonomikoa, aldaketa klimatikoa eta Informazio eta Komunikazio Teknologien (IKT) iraultza. Hiru makro-dinamika horiek forma hartuko dute ekimen berritzaileen bitartez. Maila desberdineko ikuspegia kontuan hartuz gero, proiektu horren ikerketa taldearen arabera Berrikuntza Sozialak praktika berriak maila mikroan egiteari garrantzia emango dio eta gainera aldaketa sakonagoak eragingo ditu berrikuntza, inflexio-puntu, aldaketa-kontakizun eta gizarte-eraldaketaren bitartez. Aldaketarako eta berrikuntzarako lau bide horiek batera garatzen badira aldaketa sozio-ekonomiko zabalagoa ekarriko du. Hala eta guztiz ere, behetik gorako ekimenen eta merkatu-ekonomia kapitalistaren egituraren arteko lotura oinarrizko lanketa xinple baten bitartez egiten da. Krisiaren fenomenoa deskribatzen denean ez da eraldaketarako teoria bat eraikitzen eta gainera hori ez da kausa-mekanismoekin lotzen.

TRANSIT proiektuak lau urteko ibilbidea eduki du, 2014ko urtarriletik 2017ko abendura arte. Europako Batzordeak aldi berean finantzatu du. Proiektuaren helburua Berrikuntza Sozial Eraldatzailearen teoria bat finkatzea izan da gizartearen ahalduntzea eta aldaketa burutzeko. TRANSIT proiektuak erabili duen ikerketa metodoak enpresari, berritzaile, legegile eta akademikoen arteko berrelikadura sustatu du. Proiektu horretan Europa eta Latinoamerikako nazioarteko 20 sareetan konektatuta dauden berrikuntza sozialak aztertu dira. Hala ere zenbait autoreentzat proiektu horretan erabiltzen den Berrikuntza Sozial Eraldatzailea ez da nahikoa gaur egungo egitura politikoa eta ekonomikoa gainditzeko.

Novy-ren (2017) arabera TRANSIT proiektuak ez du Berrikuntza Soziala jarri sistemaren eraldaketaren mesedera. TRANSIT programak aplikatu duen Berrikuntza Soziala gehiago aritu da neoliberalismoaren korronte nagusiaren barruan mikro aldaketak burutzen benetako eraldaketa sakona bultzatu gabe. Novy-k (2017) berak ere bere Berrikuntza Sozial Eraldatzaile propioa lantzen du. Berarentzat Berrikuntza Sozial Eraldatzailea errealitatea bihurtze eta azaleratzearen prozesu iraunkorra bezala nabaritzen duen ontologian oinarritzen da. Novy-rentzat (2017) Berrikuntza Sozial Eraldatzaileak errealismo kritikoa, transdisziplinaritatea eta pentsamendu utopikoa behar du. Eraldaketa ez da itxura aldaketa txiki bat, 
forma aldaketa sakon bat baizik. Eraldaketa horiek hobeto ulertzeko prozesuetan oinarritutako filosofiaren zientzia behar da. Hau da, errealitatea, natura eta gizartea aztertzeko prozeduran oinarritutako ulermena garatzea eskatzen du. Eraldaketa kolektibo kontzienteak forma sozialak ikastea esan nahi du erakundeak, diskurtsoak eta bizitzeko moduak aldatzeko.

Frank Moulaerten ikerketa tradizioak ere beti azpimarratu izan ditu Berrikuntza Sozialaren ahalduntze eta eraldaketa dimentsioak (Moulaert, MacCallum, Mehmood eta Hamdouch, 2013). Moulaertek argudiatzen du Berrikuntza Soziala praktika bat dela giza-zintzotasuna zentzu zabalean hobetzeko, garapen eta hazkunde materialistatik haratago joanez. Gainera, nabarmentzen du Berrikuntza Sozial horren helburu nagusiak, besteak beste, erakundeak eraldatzea, botere-egitura zapaltzaileak kentzea, bete gabeko beharrak lortzeko ekimen kolektiboak burutzea eta behetik gorako giza-erlazioen ahalduntzea direla. Ondorioz, edozein ikerketan teoria praktikarekin lotu behar da ekintza eta hausnarketa elkarlotuta doazelako.

Ungerrek (2015) ere Berrikuntza erradikalaren bidea aipatzen du. Autore horrek Berrikuntza Sozial minimalista eta Berrikuntza Sozial maximalistaren kontzeptuak erabiltzen ditu. Berrikuntza Sozial minimalistak aurpegi gizatiarra jartzen dio bestela jasangaitza izango zen egoera bateri. Aldiz, Berrikuntza Sozial maximalistak aldaketa sakonak aldarrikatzen ditu. Ungerrek (2015) esperimentatzeko metodo berri bat eskaintzen du. Metodo horrek aldaketa lortzen du gizarte-ingeniaritza sozialdemokratatik aldenduz. Gerra ondorengo kapitalismoaren ongizate sozialdemokratarekin gizarte politika eraginkorra izan da. Eredu hori zentralista, burokratikoa eta homogeneizatzailea kontsidera daiteke. Urteak joan ahala gizarte-ingeniaritza sozialdemokrata hori desegiten eta ospea galtzen joan ondoren eraldaketarako metodo aurrerakoi bat aurkitzeko premiazko behar bat sortzen da. Eraldaketarako metodo horrek beste mundu baten aldeko pentsamendu ameslaria gaur egungo errealitate pragmatikoarekin lotuko du. Ungerrek (2015) proposatzen duen esperimentazioak egitasmo bikoitza dauka, erradikala eta erreformista. Eskala txiki eta epe luzeko eraldaketen arteko dialektika hori egoki garatzeko berrikuntza sozial maximalistak behar dira, zatika eta graduala metodoetan baina bestalde erradikala asmoetan.

Hala ere, Berrikuntza Sozial Eraldatzailearen hurbiltze desberdinak aurkeztu ondoren gure artikulu honetan urrutiago joan nahi da. Berrikuntza Sozialari «Eraldatzailea» terminoa gehitzen zaio kapitalismoari aurre egingo dion beste eredu alternatibo bat eraikitzeko tresna egokia izan nahi duelako. Hain zuzen ere, Berrikuntza Sozial Eraldatzaileak esanahi politiko-ideologiko sendoa eduki nahi du. Bereziki, giza garapena bilatzen duten mugimendu sozial eta politikoentzat gida indartsua bihurtzeko.

Guretzat Berrikuntza Sozial Eraldatzailearekin apustua eta nahia beste garapen eredu alternatibo bat eraikitzea da. Hau da, beste eredu ekono- 
miko alternatiboaren bidean Berrikuntza Sozial Eraldatzailearen kontzeptua mahai-gaineratu nahi da. Horretarako garrantzitsua da Berrikuntza Sozial Eraldatzailearen rola ondo finkatzea eta diskurtso sozio-politiko alternatiboak eraikitzea aldaketa sozialaren aldeko potentzialtasuna garatzeko. Lehiakortasunaren tesiaren aurrean Berrikuntza Sozial Eraldatzaileak antitesi bat eskaini behar du eta, era berean, elkartasunezko kontra-ideologia iradokitzen du. Aldi berean, Berrikuntza Sozial Eraldatzaileak mobilizatzeko berezko joerarekin batera kapitalismoak eragindako bazterketa, alienazioa eta baliabideen eskasiaren aurka agertzen da. Sarritan zapaltzailea den egitura instituzional nagusiaren kontra erreakzionatzea Berrikuntza Sozial Eraldatzailearen eginkizun garrantzitsua izan beharko luke. Hain zuzen ere, artikulu honetan bultzatzen den Berrikuntza Sozial Eraldatzailea definitzeko eta zehazteko hiru aldagaien arabera egituratu da proposamena:

1. Berrikuntzaren izaera. Berrikuntzaren izaera kontuan hartzen bada Berrikuntza Sozial Eraldatzailea gizartearen eraldaketara bideratuko da. Horrek esan nahi du bere helburua gizarte eredu berri bat eraikitzeko prozesu eraldatzaileak martxan ipintzea dela. Gainera, xede hori lortzeko kontzeptuak, teoriak, praktikak eta estrategiak elkarlotuko dira.

Prozesu eraldatzaile horiek neoliberalismoak azken hamarkadetan garatu duen ingurumenetik abiatuko dira. Hain zuzen ere, jokaleku neoliberala mugimenduan dagoen esparru bat izanik aukera sortzaileak egon daitezke. Ez hori bakarrik, espazio sozial alternatiboak sortu nahi dira balore indibidualista, kontsumista eta atzerakoiekin funtzionatzen duten sare eta guneei aurre egiteko. Elkarren arteko elkarrizketa sendotuko da eta proposamen desberdinak erkatuko dira gehiengoaren helburuak batzen dituenak eraikitzen joateko.

Gero espazio ekonomiko, sozial eta politiko alternatibo horiek erreferentzia puntuak bihurtzea da helburua. Arnasgune horiek prozesu eraldatzailearen zabaltze estrategian paper garrantzitsua joka dezakete. Esperientzia positibo eta eraldatzaile horiek ezagunak egiten diren heinean beste espazio batzuetara garraiatuko dira.

Tokian tokiko proposamenak nazioarteko dinamikekin lotuko dira. Bertako esperientzia emankorrak nazioarteko sare alternatiboetara bideratuko dira. Horrekin batera, informazio-trukaketa indartu, jarduera-ildoak burutu eta koordinazio-dinamikak martxan ipiniko dira.

Berrikuntza Sozial Eraldatzailea garatzeko ezinbestekoa da balioen dimentsioari garrantzia ematea. Aldaketa soziala bultzatzeko baliodun pertsonak ezinbestekoak dira. Hain zuzen ere, Berrikuntza So- 
zial Eraldatzailearen azpian dauden balioek korronte nagusiko balioen aurrez aurre egon beharko dute. Aldaketa sozial aurrerakoia lortzeko, besteak beste, irabazi asmorik gabeko jarduera ekonomikoan oinarritutako eredu alternatiboak, pertsonen autogestioa, zuzeneko inplikazioa erabakitzeko ahalmen-prozesuetan, justizia sozialaren bilaketa, aukera berdintasuna eta genero parekidetasuna bultzatu beharko dira.

Bestalde, prozesu eraldatzaileak martxan ipintzeko gatazkaren dimentsioa txertatzea ere garrantzitsua da. Kasu askotan gatazka sortzea ezinbestekoa da, urratsak emateko, konponketak bilatzeko eta desoreka sozial, ekonomiko eta ekologikoak gainditzeko. Bidegabekeria bat gertatzen denean, giza eskubideak errespetatzen ez direnean, zapalkuntza egoera bat ematen denean gatazka pizten bada horrek atentzioa sortzen du eta arazo horretan inplikatuta dauden aktore desberdinak ardurapean ipintzen ditu mekanismo desberdinen bitartez irtenbide zentzuzkoak eta sortzaileak lortzeko. Zentzu horretan gatazka gizarte eraldaketaren iturri da eta, gainera, eraginkorra izan daiteke kapitalismoak eragindako desorekak eta bidegabekeriak salatzeko eta, bide batez, proposamen alternatibo egingarriak inplementatu arazteko.

2. Berrikuntzaren dimentsio soziala. Berrikuntza Sozial Eraldatzailearen azken helburua ez da bete gabeko edo gaizki betetako behar sozialei aurre egitea. Ez eta ere esku hartze sozialari buruz bakarrik aritzea. Gizartearen eraldaketa integralaren dimentsioari heldu nahi dio. Xedea beste garapen eredu alternatibo bat eraikitzea da planetaren etorkizuna bermatzeko, lurraren bioaniztasun ekologikoa, kulturala eta linguistikoa sostengatzeko eta mundu parekidea, justu, bidezkoa eta solidarioa eraikitzeko. Horregatik, Berrikuntza Sozial Eraldatzaileak arlo ekonomikoa, soziala, kulturala, politikoa, ekologikoa, ideologikoa eta etikoa landuko ditu eta genero berdintasuna helburu bezala jarriko du.

Berrikuntza Sozial Eraldatzaileak premia materialak baino zerbait gehiago asetu nahi ditu. Pertsona protagonista izango den gizartearen eraikuntzan inbertitu nahi du. Indar guztiak gizarteko premia indibidual eta kolektiboak asetzeko antolatuko dira. Hau da, ekonomia pertsona eta kolektibitatearen zerbitzura jarriko da eta ez alderantziz. Berrikuntza Sozial Eraldatzaileak estatuaren esku hartzea gizartearen gehiengoaren alde burutuko du. Hau da, antolaketa instituzional konprometitua izan behar du, lankidetza-gobernantzan oinarrituz, sektore behartsuei lehentasuna emanez, hiritar guztiei gizarte zerbitzuak eta segurtasuna eskainiz, hiritar ororentzat oinarrizko eskubide sozialak bermatuz, ondasunaren banaketa gauzatuz, zer- 
bitzu publiko egokiak bermatuz eta gizarte eta ekonomia alorreko desberdintasunak gaindituz.

Berrikuntza Sozial Eraldatzaileak merkatuaren paper positiboa bultzatuko du, beti ere sektore herrikoi zabalen alde arituz. Kontuan hartu behar da merkatuak paper bikoitza jokatu dezakela. Desberdindu egin beharko da klase herrikoien interesen alde aritzen den merkatua merkatu inperfektu txar batetik. Hau da, Berrikuntza Sozial Eraldatzaileak merkatu eraginkorra sustatuko du, gizartearen interes indibidual eta kolektiboekin bat eginez eta enpresa-ahaleginak eta ekimen pribatuak kolektiboaren mesedera bideratuz.

Gainera, Berrikuntza Sozial Eraldatzaileak Ekonomia Sozial Eraldatzailearen ahalmen guztia askatuko du. Kontuan hartu behar da Ekonomia Sozial Eraldatzailea Berrikuntza Sozial Eraldatzailearen tresna estrategikoa dela, harrobia eta sustatzailea. Prozesu eraldatzaileak martxan ipintzeko euskarrietako bat baita ere.

3. Berrikuntzaren antolaketa. Prozesu eraldatzailea antolatu egin behar da neoliberalismoaren aurrean beste eredu transformatzaile sendo eta posible bat eraikitzeko. Helburu hori lortzeko elkartasuna, integrazioa eta elkarlana bultzatuko da indibidualismoa, sektorializazioa eta zatiketa alboratuz.

Gainera, estrategia egokia antolatzeko aztertu behar da zein den gaur egungo sistema neoliberalaren eta Berrikuntza Sozial Eraldatzailearen dinamiken arteko dialektika. Baita ere, komeni da ikertzea eta aurreikustea zeintzuk diren gaur egungo sistema ekonomikoaren dinamika baztertzaileak eta atzerakoiak Berrikuntza Sozial Eraldatzaileak kontra erreakzionatzeko. Kontuan hartu behar da ere zein ekimenek hobetzen duten gizartearen balioak, zein mugimendu sozial edo politiko diren garrantzitsuak aldaketa sozialerako eta zeintzuk diren dinamika sozio-politiko eta instituzional egokiak Berrikuntza Sozial Eraldatzailea tokiko komunitateetan eta enpresetan garaile ateratzeko.

Hiritarren auto-eraketarekin batera eraldaketaren aldeko indar sozial, sindikal, politiko eta instituzionalak bat egingo dute. Antolaketa hori herri eta auzoetan gauzatuko da tokiko arazoak konpontzeko, baina baita herrialdean, nazioan eta nazioartean ere. Elkarren arteko elkarrizketa, koordinaketa eta lan amankomuna sustatuko da urratsez urrats aurrerapenak lortzeko. Hain zuzen ere, epe motzeko pausoak epe erdiko eta epe luzeko pausoekin lotuz. Egin beharreko bidea eta tokian tokiko testuingurua kontuan hartu behar dira estrategia egokia plazaratzeko. Proposamen teorikoak ere praktikarekin uztartzea komeni da egungo errealitatetik abiatuz. Beti ere, korronte neoliberalak asimilatu gabe. 


\section{1. taula}

Berrikuntza Sozial Eraldatzailearen giltzarri nagusiak

\begin{tabular}{|c|c|c|}
\hline $\begin{array}{l}(1) \\
\text { Berrikuntzaren } \\
\text { izaera }\end{array}$ & $\begin{array}{c}(2) \\
\text { Berrikuntzaren dimentsio } \\
\text { soziala }\end{array}$ & $\begin{array}{l}(3) \\
\text { Berrikuntzaren } \\
\text { antolaketa }\end{array}$ \\
\hline $\begin{array}{l}\text { KA P I T A L I S M O A R I } \\
\text { AURRE EGINGO DION } \\
\text { EREDU ALTERNATI- } \\
\text { BOA ERAIKI } \\
\text { - Prozesu eraldatzaileak } \\
\text { martxan ipini: } \\
\text { - errotikako eraldake- } \\
\text { tak korronte neolibe- } \\
\text { ralak asimilatu gabe. } \\
\text { - kontzeptuak, teoriak, } \\
\text { praktikak eta estrate- } \\
\text { giak elkarlotu. } \\
\text { - neoliberalismoak ga- } \\
\text { ratu duen ingurume- } \\
\text { netik abiatu. } \\
\text { - espazio sozial alterna- } \\
\text { tiboak sortu sare eta } \\
\text { gune neoliberalei au- } \\
\text { rre egiteko. } \\
\text { - espazio ekonomiko, } \\
\text { sozial eta politiko al- } \\
\text { ternatibo horiek erre- } \\
\text { ferentzi puntuak } \\
\text { bihurtu. } \\
\text { arnasgune horiek eza- } \\
\text { gunak egiten diren } \\
\text { heinean beste espazio } \\
\text { batzuetara garraiatu. } \\
\text { tokian tokiko propo- } \\
\text { samenak nazioarteko } \\
\text { dinamikekin lotu. } \\
\text { Informazio trukaketa } \\
\text { indartu eta jarduera } \\
\text { ildoak burutu. }\end{array}$ & $\begin{array}{l}\text { - Azken helburua ez da } \\
\text { bete gabeko edo gaizki } \\
\text { betetako behar sozialei } \\
\text { aurre egitea. } \\
\text { - Ez eta ere esku hartze } \\
\text { sozialari buruz bakarrik } \\
\text { aritzea. } \\
\text { — Gizartearen eraldaketa } \\
\text { integralaren dimen- } \\
\text { tsioari heldu: } \\
\text { - garapen eredu alter- } \\
\text { natiboa eraiki. } \\
\text { - arlo ekonomikoa, } \\
\text { soziala, kulturala, } \\
\text { politikoa, ekologi- } \\
\text { koa, ideologikoa eta } \\
\text { etikoa landu eta ge- } \\
\text { nero berdintasuna } \\
\text { helburu. } \\
\text { - pertsona eta kolekti- } \\
\text { bitatea protagonista } \\
\text { izango den gizartea- } \\
\text { ren eraikuntzan in- } \\
\text { bertitu. } \\
\text { - Estatuaren esku har- } \\
\text { tze a gi zart e a r e n } \\
\text { gehiengoaren alde bu- } \\
\text { rutu: } \\
\text { - antolaketa institu- } \\
\text { zional konprometi- } \\
\text { tua. } \\
\text { - Lankidetza-gober- } \\
\text { nantza ezarri. } \\
\text { sektore behartsuei } \\
\text { lehentasuna eman. }\end{array}$ & $\begin{array}{l}\text { - Estrategia egokia eratu: } \\
\text { gaur egungo eredu } \\
\text { neoliberalaren eta Be- } \\
\text { rrikuntza Sozial Eral- } \\
\text { datzailearen arteko } \\
\text { dialektika zehaztu. } \\
\text { - sistema neoliberala- } \\
\text { ren dinamika baz- } \\
\text { tertzaileak eta atze- } \\
\text { rakoiak aurreikusi } \\
\text { horien kontra erreak- } \\
\text { zionatzeko. } \\
\text { gizartearen baloreak } \\
\text { sendotzen dituzten } \\
\text { ekimenak ezagutu. } \\
\text { - aldaketa sozialerako } \\
\text { garrantzitsuak diren } \\
\text { mugimendu sozial } \\
\text { eta politikoak identi- } \\
\text { fikatu. } \\
\text { prozesu eraldatzaileak } \\
\text { tokiko komunitatee- } \\
\text { tan eta enpresetan ga- } \\
\text { raile ateratzeko dina- } \\
\text { mika sozio-politikoak } \\
\text { eta instituzionalak } \\
\text { antzeman. } \\
\text { - Antolaketa herri eta au- } \\
\text { zoetan gauzatu, baita } \\
\text { ere herrialdean, nazioan } \\
\text { eta nazioartean: } \\
\text { - eraldaketaren aldeko } \\
\text { indar sozial, sindikal, } \\
\text { politiko eta institu- } \\
\text { zionalak bat egin. }\end{array}$ \\
\hline
\end{tabular}




\begin{tabular}{|c|c|c|}
\hline $\begin{array}{l}(1) \\
\text { Berrikuntzaren } \\
\text { izaera }\end{array}$ & $\begin{array}{c}(2) \\
\text { Berrikuntzaren dimentsio } \\
\text { soziala }\end{array}$ & $\begin{array}{l}\text { (3) } \\
\text { Berrikuntzaren } \\
\text { antolaketa }\end{array}$ \\
\hline $\begin{array}{l}\text {-Gatazkaren beharra al- } \\
\text { daketa eragiteko: } \\
\text { - gatazka ezinbestekoa } \\
\text { da urratsak emateko, } \\
\text { konponketak bila- } \\
\text { tzeko eta desoreka } \\
\text { sozio-ekonomikoak } \\
\text { gainditzeko. } \\
\text { gatazkak atentzioa } \\
\text { deitu eta inplikatu- } \\
\text { tako aktoreak irten- } \\
\text { bide zentzuzkoak eta } \\
\text { sortzaileak lortzera } \\
\text { behartzen du. } \\
\text { gatazka gizarte eral- } \\
\text { daketaren iturri da, } \\
\text { kapitalismoak eragin- } \\
\text { dako bidegabekeriak } \\
\text { salatzeko eta propo- } \\
\text { samen egingarriak in- } \\
\text { plementatzeko. }\end{array}$ & $\begin{array}{l}\text { - hiritar guztiei gizarte } \\
\text { zerbitzuak eta segur- } \\
\text { tasuna eskaini. } \\
\text { - hiritar ororentzat oi- } \\
\text { narrizko eskubide } \\
\text { sozialak bermatu. } \\
\text { - politika birbanatzai- } \\
\text { leak gauzatu. } \\
\text { - zerbitzu publiko } \\
\text { egokiak bermatu. } \\
\text { gizarte eta ekonomia } \\
\text { alorreko desberdin- } \\
\text { tasunak gainditu. } \\
\text { Merkatuaren paper po- } \\
\text { sitiboa bultzatu: } \\
\text { - merkatua eraginko- } \\
\text { rra denean. } \\
\text { merkatuak bat egi- } \\
\text { ten duenean gi- } \\
\text { zartearen interes } \\
\text { indibidual eta ko- } \\
\text { lektiboekin. } \\
\text { enpresa-ahaleginak } \\
\text { eta ekimen priba- } \\
\text { tuak kolektiboaren } \\
\text { mesederako dire- } \\
\text { nean. } \\
\text { - Ekonomia Sozial Eral- } \\
\text { datzailearen ahalmen } \\
\text { guztia askatu: } \\
\text { Ekonomia Sozial } \\
\text { Eraldatzailea Berri- } \\
\text { kuntza Sozial Eral- } \\
\text { datzailearen tresna } \\
\text { estrategikoa, harro- } \\
\text { bia eta sustatzailea } \\
\text { da. }\end{array}$ & $\begin{array}{l}\text { - elkarren arteko elka- } \\
\text { rrizketa, koordina- } \\
\text { keta eta lan amanko- } \\
\text { muna sustatu. } \\
\text { - } \text { aurrerapenak urratsez } \\
\text { urrats eman, epe mo- } \\
\text { tzeko pausoak epe er- } \\
\text { diko eta epe luzeko } \\
\text { pausoekin lotuz. } \\
\text { tokian tokiko testuin- } \\
\text { gurua eta egin beha- } \\
\text { rreko bidea kontuan } \\
\text { hartu estrategia ego- } \\
\text { kia plazaratzeko. } \\
\text { - proposamen teo- } \\
\text { rikoak praktikare- } \\
\text { kin uztartu, egungo } \\
\text { errealitatetik abiatuz. } \\
\text { demokrazia parte- } \\
\text { hartzailea bultzatu. } \\
\text { Prestakuntza ideologi- } \\
\text { koa sustatu: } \\
\text { - hiritarrak formatu } \\
\text { behar dira gizarte eta } \\
\text { ekonomia gaiak uler- } \\
\text { tzeko eta aztertzeko. } \\
\text { segurtasuna lortu } \\
\text { talde dinamika ego- } \\
\text { kiak antolatzeko eta } \\
\text { herri eta auzoetako } \\
\text { arazoei heltzeko. } \\
\text { komunikazioa landu } \\
\text { antolatutako dina- } \\
\text { mika eraldatzaileak } \\
\text { gizarteratzeko. }\end{array}$ \\
\hline
\end{tabular}

Iturria: Geuk egina (2018). 
Berrikuntza Sozial Eraldatzaileak demokrazia parte-hartzailea ere sustatuko du. Hain zuzen ere herritarren parte hartzearekin hartuko dira erabaki sozial, politiko eta ekonomiko garrantzitsuenak. Informazioa lortzeko, eztabaida egokiak burutzeko eta erabakiak hartzeko Berrikuntza Sozial Eraldatzaileak parte hartzeko tresna egokiak antolatu beharko ditu.

Ilusioa sortu eta transmitituko duten pertsona militanteak animatzea eta antolatzea garrantzitsua da gustuko duten esparruetan lan egiteko. Horretarako zor zaion garrantzia emango zaio prestakuntza ideologikoari. Hiritarrak formatu behar dira gizarte eta ekonomia gaiak ulertzeko eta aztertzeko. Segurtasuna lortzea garrantzitsua da talde dinamika egokiak antolatzeko eta herri eta auzoetako arazoei heltzeko. Baita ere, komeni da ere komunikazioa lantzea antolatutako dinamikak gizarteratzeko.

Aldi berean, Berrikuntza Sozial Eraldatzailea gai izan behar da botere politiko subiranoa eratzeko oinarri oinarrizko eremuetatik hasita. Ahalik eta deszentralizazio administratiborik handiena bilatu beharko luke eta horretarako udal eta tokiko erakundeei eskumenak eta beharrezko baliabideak esleitzeko balio beharko du.

\section{Ondorioak}

Artikulu honetan Berrikuntza Sozial Eraldatzailearen funtzioa ondo finkatzeari lehentasuna eman zaio, ikuspegi sozio-politiko alternatiboak sortzeko eta eraldaketa sozialaren aldeko ahalmena garatzeko. Azken finean, gizartearen eraldaketara bideratutako Berrikuntza Sozialaren kontzeptuak, teoriak, praktikak eta estrategiak elkarlotu dira gaur egungo eredu neoliberalari aurre egiteko eta inongo bazterketarik gabeko mundu bat eraikitze bidean urrats sendoak emateko.

Bide horretan Berrikuntza Sozial Eraldatzaileak oinarri politiko eta ideologiko argiak eduki behar ditu bere potentzialitate guztia gizarte-eraldaketara bideratzeko. Hain zuzen ere, komeni da Berrikuntza Sozial Eraldatzailearen eginkizuna ondo kokatzea hausnarketa sozio-politiko alternatibo egokiak plazaratzeko eta praktikara eramateko. Zentzuzko alternatibak plazaratu dira. Horretarako sormena, antolaketa egokia, herritar desberdinen mobilizazio ahalmena eta instituzioei zuzendutako lankidetza eta interpelazioa erabili da. Garrantzitsua da jarduera horien arteko halako oreka bat bilatzea errendimendu sozial eta politikorik handiena gauzatzeko. Berrikuntza Sozial Eraldatzailearen helburua teoria politiko-ideologiko horiek martxan ipintzea izan da orain arte berrikuntzan eta arlo politikoan nagusi 
izan diren aurrerapen teknikoan eta irabazian oinarritutako diskurtsoetatik aldentzeko.

Azpimarratu daiteke baita ere Berrikuntza Sozial Eraldatzailean garrantzia alternatiben hedapenak eta sustapenak hartzen dutela. Behar handi bat dago praktika hoberenen forma aurrerakoiak hedatzeko eta iraunarazteko. Berrikuntza Sozial Eraldatzaileak benetako protagonismoa ematen dio eguneroko praktikan gauzatzen den eraldaketa sozialari. Hori dela eta, prozesu eraldatzailearen lehenbiziko helburua ekonomia eta gizarte eredu alternatiboa eraikitzea da. Komeni da elkarren arteko lankidetza azpimarratzea, proposamenak alderatzea eta lan egitea, erronka garrantzitsuei aurre egiteko, hala nola, herritarren gehiengoaren bizi kalitatea hobetzea, lana eta aberastasuna banatzea eta guztion helburuak batzen dituen ekimen sozio-ekonomikoa sakontzea. Eta teoria hutsean geratu gabe prestaturiko proposamenak praktikara eraman behar dira egungo errealitatetik abiatuz.

Argi eta garbi, krisiaren baldintzak bakarrik ez du bermatzen neoliberalismoaren kontrako ildoaren indarketa. Berrikuntza Sozial Eraldatzaileak esparru sozial alternatiboak sortu behar ditu balore indibidualista, kontsumista eta erreakzionarioekin funtzionatzen duten sare eta guneei aurre egiteko. Alternatiba aurrerakoiak garatzeko beharra, bideragarritasuna eta iraunkortasuna ez da nahikoa proiektu horiek gauzatzeko. Berrikuntza Sozial Eraldatzaileak ahalmena dauka neoliberalismoak azken hamarkadetan garatu duen ingurumen egituratu eta errotuan prozesu eraldatzaileak martxan ipintzeko. Hain zuzen ere, denbora horretan merkatuaren eta korporazioen aldeko arrazionaltasunak bat egin du egitura sozial, korporatibo eta finantzarioekin eta, aldi berean, estatu-boterearekin eta ez da erraza «humus» horretan kimu aurrerakoi berriak ernaltzea. Espazio ekonomiko, sozial eta politiko alternatibo horiek erreferentzia puntu garrantzitsuak bihur daitezke esperientzia positibo eta eraldatzaile horiek ezagunak egiteko eta gero beste espazio batzuetara garraiatzeko. Hau da, arnasgune horiek prozesu eraldatzailearen zabaltze estrategian paper garrantzitsua jokatzen dute.

Berrikuntza Sozial Eraldatzaileak bultzatu nahi duen prozesu eraldatzailea gaur egungo jokaleku neoliberaletik abiatzen da. Jokaleku neoliberal horretan, mugimenduan dagoen esparru bat izanik, aukera sortzaileak egon daitezke. Formulazio hori onartzen bada, neoliberalismoa ezaugarritu daiteke ez bakarrik muga garrantzitsuak dituen eredu bat bezala, baita ere aukera politikorako erregistro berrien jokaleku gisa. Horretarako egunez egun urratsak eman behar dira, norabide onean, iparra ondo finkatuz, epe motzeko urratsak epe erdiko eta luzeko urratsekin lotuz, garapen teorikoak errealitateko praktikarekin koordinatuz. Baino, beti ere, korronte neoliberalak asimilatu gabe. 


\section{Bibliografia}

Ayob, N., Teasdale, S., eta Fagan, K. (2016). How Social Innovation 'Came to Be': Tracing the Evolution of a Contested Concept. Journal of Social Policy, 45(4), 635-653.

Bouchard, M.J. (2006). De l'experimentation à l'institutionnalisation positive, l'innovation sociale dans le logement communautaire au Quebec. Annales de l'économie publique, sociale et cooperative, 77(2), 139-166.

Bouchard, M.J. (2007). L'innovation sociale en économie sociale. In J.-L. Klein eta D. Harrison (dir.), L'innovation sociale, émergence et effets sur la transformation des sociétés. Québec: Presses de l'Université du Québec.

Bouchard, M.J. (2013). The Social Economy in Québec: a Laboratory of Social Innovation. In M.J. Bouchard (Ed.), Innovation and the Social Economy (3-24 orr.). Toronto: University of Toronto Press.

Bovaird, T., eta Loeffler, E. (2012). From engagement to co-production: how service users and communities contribute to public services. In V. Pestoff, T. Brandsen and B. Verschuere (eds), New Public Governance, The third Sector and Coproduction (35-60 orr.). London: Routledge.

Brandsen, T., eta Pestoff, V. (2006). Co-production, the third sector and the delivery of public services. Public Management Review, 8(4), 493-501.

Brundtland, G.H. (1987). Nuestro futuro común. Informe de la Comisión Mundial sobre el Medio Ambiente y el Desarrollo. New York: Asamblea General de la ONU.

Chambon, J.-L., David, A., eta Devevey, J.M. (1982). Les innovations sociales. Paris: Presses Universitaires de France.

Drucker, P. (1987). Social Innovation: management's new dimension. Long Range Planning, 20(6), 29-34.

Duñaiturria, S. (2007). Influencia de la Filosofía contemporánea en el progreso de la humanidad: alternativa al neoliberalismo. Bilbo: Erroteta.

Hillenkamp, I. (2016). ¿Innovar para sostenerse? Representaciones y prácticas de Economia Popular Solidaria en América Latina. In C. Puig, Economía Social y Solidaria: conceptos, prácticas y políticas públicas (65-82 orr.). Bilbao: UPV/ EHU, Hegoa.

Hoggan, F. (1909). The American negro and race blending. The Sociological Review, 2(4), 349-360.

Klein, J.L. (2013) Introduction: social innovation at the crossroads between science, economy and society. In F. Moulaert, D. MacCallum, A. Mehmood eta A. Hamdouch, The International Handbook on Social Innovation (9-12 orr.). Cheltenham, UK: Edward Elgard Publishing Limited.

Klein, J.-L., eta Harrison, D. (2010). L'innovation sociale. Émergence et effets sur la transformation des sociétés. Québec: Presses de l'Université du Québec.

Lévesque, B. (2006). Le potentiel d'innovation et de transformation de l'economie sociale : quelques éléments de problematique. Economie et Solidarités, 37(2), $13-48$. 
Lévesque, B. (2011) Un monde qui se défait, un monde à reconstruire. L'Action nationale, $133,157-184$.

Mendizabal, A. (2012). Aproximación a la autogestión en la economía de mercado. Saarbrücken: Editorial Académica Española.

Moulaert, F., MacCallum, D., eta Hillier, J. (2013). Social innovation: intuition, precept, concept, theory and practice. In F. Moulaert, D. MacCallum, A. Mehmood eta A. Hamdouch, The International Handbook on Social Innovation (13-24 orr.). Cheltenham, UK: Edward Elgard Publishing Limited.

Moulaert, F., MacCallum, D., Mehmood, A. eta Hamdouch, A. (eds.). (2013). The International Handbook on Social Innovation. Cheltenham, UK: Edward Elgard Publishing Limited.

Novy, A. (2017). Transformative Social Innovation. SRE-Discussion Papers, 2017/05. Vienna: WU Vienna University of Economics and Business.

Peck, j. (2013). Social Innovation... at the limits of neoliberalism. In J.L. Klein eta M. Roy (dir.), Pour une nouvelle mondialisation, le défi d'innover (11-29 orr.). Québec : Presses de l'Université du Québec.

Pol, E. eta Ville, S. (2009). Social Innovation: Buzz word or enduring term? The Journal of Socio-Economics, 38(6), 878-885.

Richez-Battesti, N., Petrella, F., eta Vallade, D. (2012). L'Innovation sociale, une notion aux usages pluriels: Quels enjeux et défis pour l'analyse? Innovations, 38, 15-36.

Tarde, G. (1899). Social laws: an outline of sociology. New York: Macmillan.

TRANSIT (2018). Transformative Social Innovation theory. The TRANSIT Project. http:/www.transitsocialinnovation.eu/, 2018ko ekainaren 23an begiratua.

Unger, R.M. (2015). Conclusion: the Task of the Social Innovation Movement. In A. Nicolls, J. Simon, eta M. Gabriel (eds.), New Frontiers in Social Innovation Research (233-251 orr.). Hampshire: Palgrave Macmillan. 



\title{
El cooperativismo danés en el sistema societal de alternativas al capitalismo.
} Trayectorias nacionales y dinámicas transnacionales

\author{
Danish cooperativism in the societal system of alternatives to capitalism.
} National trajectories and trans-national dynamics

Manuel AHEDO

Profesor a tiempo parcial de la Facultad de Ciencias Sociales de la Universidad de Copenhague (Dinamarca)

\begin{abstract}
Resumen: El cooperativismo en Europa se ha mantenido como una importante tradición de organización socioeconómica alternativa a las formas capitalistas dominantes, y es parte del sistema societal de alternativas al capitalismo. Este sistema se fundamenta en la construcción de formas colectivas y cooperativas de producción e intercambio. La sociedad de Dinamarca se caracteriza por ser una sociedad de ciudadanos/as-trabajadores/as empoderados/as. Para entender el papel del cooperativismo en el sistema nacional danés de alternativas al capitalismo se realiza un doble análisis: a) un análisis del tipo de cooperativismo danés con sus variantes y trayectorias particulares, y b) un análisis de la coevolución del cooperativismo en relación a otros movimientos que han desarrollado la dimensión colectiva en la socioeconomía, en concreto el movimiento laboral-sindical y el movimiento socialdemócrata de bienestar público. El análisis nacional se enmarca en el contexto regional de los países nórdicos y de Europa.
\end{abstract}

Palabras clave: Historia económica; sociología económica; empresas cooperativas; movimientos sociales; capitalismo.

\begin{abstract}
The cooperatives-based movement in Europe has endured as an important tradition of socioeconomic organization alternative to the dominant capitalist forms, and it is part of the societal system of alternatives to capitalism. This system is based on and aimed at constructing collective and cooperative forms of production and exchange. Denmark's society can be defined as a society of empowered citizens-workers. In order to understand the role of Cooperatives-based movement in the Danish national-societal system of alternatives to capitalism a double analysis is made: a) an analysis of the type of cooperatives-based movement in Denmark with its variants and trajectories; and b) an analysis of the coevolution of the cooperatives-based movement in relation to other social movements that have developed the collective dimension of socioeconomic organization, namely, the labour-union movement and the social democratic movement of welfare state. This national analysis is framed within a regional context of the Nordic countries and Europe.
\end{abstract}

Keywords: Economic history; economic sociology; cooperative enterprises; social movements; capitalism.

Claves Econlit: N, Z1, P13

* Correspondencia a/Corresponding author: Manuel Ahedo. Facultad de Ciencias Sociales de la Universidad de Copenhague (Dinamarca) - manu.ahedo@gmail.com - https://orcid.org/0000-0001-5737-4802

Cómo citar/How to cite: Ahedo, Manuel (2019). «El cooperativismo danés en el sistema societal de alternativas al capitalismo. Trayectorias nacionales y dinámicas transnacionales", Gizarte Ekonomiaren Euskal Aldizkaria/Revista Vasca de Economía Social, 16, 69-101. (https://doi.org/10.1387/reves.21219).

Recibido: 30 mayo, 2019; aceptado: 4 julio, 2019.

ISSN 1698-7446 - elSSN 2444-3107 / (c) 2019 UPV/EHU

(c) (i) Esta obra está bajo una licencia

Creative Commons Atribución 4.0 Internacional 


\section{Introducción}

Cada vez son más evidentes los límites del capitalismo global dirigido por las lógicas financieras y de las grandes empresas transnacionales y multinacionales. Los efectos negativos del capitalismo global afectan a un mayor número de sociedades y grupos sociales. La economía capitalista basada en el dogma del crecimiento económico local y global genera desigualdades sociales nacionales e internacionales, además de retos como el cambio climático, desequilibrios geopolíticos y riesgos tecnocientíficos. Ante esta situación es necesario elucidar y promover formas alternativas de organización socioeconómica basadas en la búsqueda de la solidaridad, la igualdad y el respeto al medio ambiente. Las cooperativas y la economía social han demostrado ser una alternativa socialmente responsable y efectiva en muchos contextos locales como nacionales. Las Naciones Unidas declararon el 2012 como el año internacional de las cooperativas.

El cooperativismo, a pesar de no tener una alta relevancia o peso cuantitativo en las sociedades y economías contemporáneas, debe considerarse como un fenómeno relevante en la sociedad contemporánea. En ese sentido, las ciencias sociales deben prestar una mayor atención a este fenómeno social que se sitúa entre lo civil, lo económico y lo político. La sección 2 del artículo ofrece un marco de análisis para una sociología macro o institucionalista del cooperativismo, analizado como dos fenómenos: a) como una forma de organización económica alternativa al modelo capitalista de mercado y de propiedad privada, cuya naturaleza específica depende de las particularidades sistémicas societales o nacionales; y b) como un histórico movimiento social transformador y de progreso con diversas manifestaciones y significados que dentro del marco del estado-nación evoluciona junto a otros movimientos sociales transformadores, con los que de alguna manera compite y colabora.

Los fenómenos macrosociales tienen lugar en amplios contextos institucionales e históricos. Para comprender el cooperativismo danés es necesario contextualizarlo en la región nórdica y en el contexto europeo. La sección 3 presenta esa contextualización necesaria para analizar el caso concreto. En el contexto de la Unión Europea ha habido una larga tradición de organizaciones cooperativas o participativas en la producción y en el comercio o intercambio. Como argumentan Borzaga et al. (2014), la renovación del modelo social europeo de capitalismo necesita considerar la viabilidad socioeconómica de la organización cooperativa y participativa. El modelo europeo de cooperativismo y de economía social se fundamenta en un equilibrio entre tres instituciones modernas: el mercado, la sociedad civil y el estado. En ese equilibrio la importancia de la sociedad civil es una particularidad del cooperativismo o economía social europea (Kerlin, 2006; 2010). 
La sección 4 presenta los resultados de una sociología institucionalista del cooperativismo en Dinamarca. Se realizan dos análisis complementarios: a) sobre el papel del cooperativismo en el sistema societal-nacional de alternativas al capitalismo: se analiza la evolución de sus diferentes variantes de cooperativismo y la forma en que conforman el sistema alternativo complementario a la lógica capitalista; y b) una sociología histórica del movimiento cooperativista en relación con los otros movimientos sociales que han promovido la dimensión colectiva en la economía capitalista, como son el movimiento laboral-sindical y el movimiento socialdemócrata de estado del bienestar.

La sección 5 analiza las últimas dinámicas del cooperativismo danés y nórdico con una especial atención al contexto europeo (Crouch, 1999). En las últimas décadas el cooperativismo ha vivido una mayor presencia institucional mientras ha tenido que coexistir con el desarrollo del neoliberalismo económico. Sin embargo, hay que reconocer que a medida que ha aumentado la crítica del modelo neoliberal, la alternativa cooperativista, ampliada bajo el concepto de economía social, se ha movido hacia posiciones más relevantes en el debate y análisis de la realidad socioeconómica. La sección 6 recoge las conclusiones y ofrece algunas reflexiones sobre el conocimiento científico-social del cooperativismo.

\section{El cooperativismo en el sistema societal de alternativas al capitalismo: trayectorias nacionales en dinámicas transnacionales}

El cooperativismo se puede concebir como una tradición histórica que ha mantenido a lo largo de la modernidad y la modernización su potencialidad y su aplicabilidad. Históricamente, el cooperativismo tuvo su momento fuerte en la emergencia de la sociedad industrial, donde antiguas tradiciones de cooperación rural fueron adaptadas al nuevo contexto industrial. La sociedad y la economía moderna se fundamentaron en la libertad individual, como ciudadano/a, trabajador/a y propietario/a. La modernidad ha traído también un mínimo de derechos sociolaborales a los/as ciudadanos/as-trabajadores/as y un marco de derechos de propiedad, y a su vez la libertad responsable y solidaria para cooperar con otros/as ciudadanos/as en la construcción de bienes comunes o colectivos. Autores clásicos en Sociología y Ciencias Sociales, como Durkheim, Weber, o de forma más explícita Polanyi (1944), han enfatizado que la economía de mercado capitalista necesita de elementos sociales y comunitarios, es decir, colectivos y no individualistas, para equilibrar sus contradicciones y para suavizar sus efectos negativos. Estos elementos escapan a la formalización contractual de las relaciones de mercado, y no son de fácil observación e identificación. 
Dentro de una sociología institucionalista o macro-cultural se analiza el cooperativismo desde dos perspectivas complementarias. En primer lugar, como forma de organización económica alternativa a la capitalista de mercado; el cooperativismo ha sido un elemento clave en el sistema (local, nacional y global) de alternativas al capitalismo. Cada sociedad ha desarrollado su particular forma de cooperativismo, conformando un conjunto de diferentes variantes de organización cooperativista según sectores de actividad. En segundo lugar, como un movimiento social en coevolución y relación con otros movimientos sociales. En concreto, se considera que el cooperativismo en la modernización económica se relaciona y contrasta con el movimiento laboral-sindical y con el movimiento socialdemócrata de bienestar. En su relación con esos dos movimientos es dónde el movimiento cooperativista encuentra su espacio y sus caminos de desarrollo.

\subsection{El cooperativismo en el sistema nacional de alternativas al capitalismo}

El capitalismo como sistema de organización socioeconómico se fundamenta en tres pilares: la propiedad privada heredable, la lógica del mercado liberal y racional, y el individualismo o decisión y opción individual. El capitalismo es el modelo socioeconómico dominante de la modernidad, a pesar de sus ambivalencias, dilemas y contradicciones. El desarrollo del capitalismo junto a la modernización ha tenido una expansión institucional. Dentro de esta modernización económica capitalista, otras formas de propiedad y de producción han ido quedado marginadas, salvo el caso de la propiedad y la producción pública gestionada por el estado o las instituciones públicas. La modernización se definió después de la Segunda Guerra Mundial en base al patrón que los Estados Unidos de América estaba desarrollando (Harrison, 2003). En ese patrón de modernización, la propiedad privada y la producción orientada al mercado quedaron naturalizados como fundamentos y patrones universales o universalizables.

Sin embargo, muchas sociedades, tanto occidentales como de todo el mundo, han mantenido tradiciones no-capitalistas de organización socioeconómica, desde las propiedades colectivas o comunitarias hasta diferentes formas de cooperación productiva o de intercambio. El nivel nacional de análisis dentro de los contemporáneos estados-nación resulta práctico para la investigación social, pero tiene algunas limitaciones para el análisis sociológico, al no ser analíticamente flexible para observar la rica y compleja realidad de las sociedades contemporáneas. Se prefiere así el enfoque societal, como fue propuesto entre otros por Maurice y Sorge (2000) para comparar la organización del trabajo en diferentes sociedades euro- 
peas. En suma, cada estado-nación ha desarrollado su propio sistema societal de alternativas al capitalismo.

En las últimas décadas de capitalismo neoliberal, autores como Wright (2010) o Castells (2017) han promovido el estudio de alternativas a la economía capitalista de mercado privado neoliberal. Entre las diferentes utopías reales recogidas por Wright el cooperativismo y la economía social han recibido un sitio relevante. Wright enfatiza los casos de las cooperativas de Mondragón y los centros de atención y cuidado infantil (guarderías) en Quebec (Canadá). Castells incluye ejemplos de otras alternativas como las comunidades de intercambio, dinero alternativo, dentro de contextos urbanos y de emergentes prácticas de compartir lo común. Entre estas prácticas alternativas, el cooperativismo ocupa un lugar importante. Estos autores identifican practicas alternativas a la economía capitalista convencional, de forma aislada de su contexto societal nacional o local, lo que dificulta conocer aspectos importantes y factores explicativos de esas prácticas.

El cooperativismo es una forma de organización económica alternativa al modelo capitalista de mercado y propiedad privada. Para definir y clasificar el cooperativismo se propone el criterio organizativo. El cooperativismo se concreta en organizaciones o empresas cooperativas. Una organización o una empresa cooperativa puede significar diversos fenómenos organizativos, puede adquirir diversas formas legales, y lo más importante, puede servir para producir una diversidad de productos y servicios. Siguiendo unos criterios clarificadores, en este artículo se ha adoptado la siguiente definición: una empresa u organización cooperativa es aquella que tiene en un mayor o menor grado los siguientes tres rasgos: a) la posibilidad de libre y voluntaria asociación; b) una estructura de gobierno democrática, en el que el principio de "un socio-un voto», bien de forma estricta o de forma cualificada, es el principio constitutivo de su toma de decisiones; y c) una distribución equitativa y justa de los resultados económicos.

Dentro de la amplia tipología de cooperativas existentes se sugiere la ventaja de clasificar estos fenómenos en tres grandes tipos de cooperativas: a) de clientes o consumidores: en las que los consumidores o usuarios de los servicios son los dueños de la organización cooperativa; en este tipo destaca el tipo clásico de cooperativas de consumo, de seguros, electricidad, etc.; b) de productores: donde los mismos productores de los productos o servicios cooperan para la comercialización de los productos; el tipo clásico son las cooperativas de transformación agropecuaria; y c) de empleados propietarios: la forma tradicional en este tipo son las cooperativas de producción o de trabajo.

Hay casos de fenómenos cooperativos que comparten características de más de un tipo, como puede ser: a) las cooperativas de viviendas, a cuales 
pueden presentar diferentes tipos y formas según la tradición de cada país; b) un tipo emergente de cooperativas, como las cooperativas de servicios sociales, educativos o de cuidado (de niños, de personas de la tercera edad, etc.); este tipo de cooperativas de carácter social, a veces también llamadas empresas sociales, se caracterizan por un tamaño reducido, por disponer de una importante fuente de financiación pública al satisfacer necesidades públicas, y por operar en campos de media-alta profesionalidad.

\subsection{El cooperativismo como movimiento social en correlación y coevolución}

La sociología y la ciencia social de los movimientos sociales ha aumentado la atención a las relaciones internas y externas de los movimientos sociales, como variables explicativas básicas del funcionamiento, éxito y declive de los movimientos sociales (Snow, Soule y Kriesi, 2004; Della Porta y Diani, 2009). Las relaciones internas permiten ver al movimiento social como una red organizadas de interacción y colaboración entre sus miembros, que genera dinámicas de acción colectiva (Melucci, 1985; Barnes, 1995). Para Melucci (1989), la creación de una identidad colectiva como base a la acción colectiva organizada es un proceso de negociación que contiene tres aspectos: a) la formación de un marco cognitivo que comprende e interpreta el entorno en el que opera, y formula los objetivos y las estrategias; b) la creación de relaciones entre los participantes y c) el estímulo de dinámicas emocionales entre los participantes internos y externos. Las relaciones externas con otros movimientos sociales u organizaciones de acción colectiva, en referencia directa o indirecta al estado, y en base a su argumentario o ideologías, su posición, su diferenciación, etc., son consideradas como las claves institucionales del éxito o fracaso de un movimiento social (Touraine, 1985). Se considera necesario analizar la evolución de las relaciones entre el movimiento social del cooperativismo con otros movimientos sociales afines con los que colabora y compite.

Las relaciones internas y externas tienen lugar en evolutivos contextos nacionales. En este análisis la atención se centra en las relaciones externas de colaboración y competencia con otros movimientos afines y próximos. Como se ha indicado anteriormente, el estado-nación moderno y contemporáneo es un nivel sustantivo y clave de la realidad social. El estado y el sistema político deben ser considerados como factores estructurales e institucionales clave para las interrelaciones entre los movimientos sociales, tal y como sugirió Smelser en los años 1960 para la realidad de los Estados Unidos. Si el cooperativismo ha sido y es una alternativa colectivista al capitalismo individualista, debe ser analizado en 
su relación con los otros movimientos sociales colectivistas. En el caso de Dinamarca, la relación externa clave del cooperativismo es con el movimiento laboral-sindical, y el movimiento socialdemócrata de estado del bienestar.

\section{El contexto general del cooperativismo danés, nórdico y europeo}

Los países escandinavos o nórdicos ${ }^{1}$ fueron pioneros en la creación de organizaciones cooperativas. A finales del siglo XIX y a principios del siglo $\mathrm{xx}$, el mundo agropecuario de estos países impulsó un fuerte movimiento cooperativo en torno a su sector de producción y transformación de productos lácteos y cárnicos, así como un cooperativismo de distribución y comercialización de productos alimenticios. A este cooperativismo agropecuario rural de coproducción y comercialización se le ha ido sumando a lo largo del siglo xx, y especialmente en la 2. ${ }^{a}$ parte del siglo xx, el cooperativismo de consumidores, de carácter más urbano (cadenas de supermercados, cooperativas de electricidad, vivienda, seguros y bancos, etc.).

En sus inicios y desarrollo, la cooperación y solidaridad del mundo rural nórdico se fundamentó en dos factores principales: a) la alta homogeneidad de la propiedad rural, conseguida a través de un temprano proceso de apropiación de la tierra por parte de arrendatarios que posibilitó el desarrollo de un sistema agropecuario basado en los pequeños propietarios; y b) la tradición luterana nórdica, donde se adaptan las ideas luteranas enfatizando la participación y la responsabilidad individual en la vida cultural y religiosa local. Ahedo (2017) lo analiza para el caso de Dinamarca.

El cooperativismo nórdico presenta tres tipos principales de organización cooperativa: de producción-comercialización, de consumo y de servicios. Los otros tipos de fenómeno cooperativo, como el de productores, de trabajo, artesanales, etc. están mucho menos desarrollados. Esto se debe principalmente a un desarrollado y negociado sistema de relaciones laborales, que facilita una serie de derechos laborales, tanto financieros como de poder y participación para los/as trabajadores/as. Los/as trabajadores/as nórdicos se describen mejor como una especie de «ciudadanos/as asalariados/as». Asimismo, cooperativas o mutuas de seguros, financieras, de salud, etc. no están tampoco muy desarrolladas, aunque hay algunas excepciones. Esto se debe al papel que ha jugado el estado para garantizar unos derechos

${ }^{1}$ En el adjetivo nórdico se incluiría a Finlandia, cuyo idioma no es de la familia germanoescandinava, y a Islandia, con una lengua de tradición vikinga. 